\title{
Analisis Dukungan Organisasi, Serikat Pekerja dan Pemerintah dalam Pengaruh Motivasi dan Komitmen terhadap Kualitas Hidup Buruh Perempuan di Jabodetabek
}

\author{
Sylvia Diana Purba' ${ }^{1}$, \\ Christine Winstinindah Sandroto ${ }^{2)}$, \\ Benedicta Evienia Prabawanti ${ }^{3)}$ \\ Unika Atma Jaya Jakarta \\ sylvia.purba@atmajaya.ac.id; selvypurba@yahoo.com ${ }^{1)}$
}

\begin{abstract}
ABSTRAK
Penelitian ini bertujuan untuk menguji moderasi dukungan organisasi, serikat pekerja dan Pemerintah dalam model pengaruh motivasi terhadap kualitas hidup yang dimediasi komitmen kontinuans di wilayah Jabodetabek Indonesia pada pekerja perempuan yang telah menikah dan memiliki anak di industri manufaktur. Sampel dilakukan dengan metode convinience dimana jumlah populasi sulit untuk diketahui. Analisis jalur yang dilakukan menggunakan sofware SPSS V.22 yang dijalankan dengan macro Hayes, 2013. Hasil penelitian menunjukkan, pada model 1 tidak ditemukan moderasi dukungan organisasi dan serikat pekerja baik pada pengaruh motivasi terhadap komitmen maupun pengaruh motivasi terhadap kualitas hidup, dimana secara simultan komitmen tidak dapat menjadi variabel mediasi. Begitupula pada model 2 secara simultan tidak ditemukan moderasi dukungan serikat pekerja dan dukungan Pemerintah dalam pengaruh motivasi dan komitmen terhadap kualitas hidup. Namun, secara terpisah model 3 membuktikan ada moderasi signifikan dari dukungan Pemerintah dalam pengaruh komitmen kontinuans terhadap kualitas hidup. Di sisi lain moderasi dukungan serikat pekerja tidak signifikan, tetapi secara bersama-sama dukungan pemerintah dan serikat pekerja dapat memoderasi komitmen dalam meningkatkan kualitas hidup buruh perempuan di Jabotabek.
\end{abstract}

Key words: motivasi, komitmen kontinuans, kualitas hidup, dukungan organisasi, dukungan pemerintah, dukungan serikat pekerja Indonesia. 
Analisis Dukungan Organisasi ... (Sylvia D., Christine W., dan Benedicta E.)

\section{PENDAHULUAN}

\subsection{Latar Belakang Masalah}

Tingkat keterampilan, pendidikan dan kualitas kerja yang rendah menjadikan banyak tenaga kerja di Indonesia bekerja sebagai buruh pabrik. Potret buruh di Indonesia dan demikian pula secara khusus di Jabotabek hampir setiap tahun melakukan demonstrasi yang intinya menuntut kualitas hidup yang lebih baik melalui perbaikan nasib dan kesejahteraan, yang di dalamnya mencakup tuntutan atas kondisi kerja yang layak, upah layak, serta jaminan hidup yang layak.

Penelitian ini, meneliti lebih lanjut mengenai buruh perempuan yang telah menikah dan memiliki anak. (Selanjutnya di artikel ini akan disebut sebagai buruh perempuan). Berdasarkan catatan Biro Pusat Statistik (BPS) pada tahun 2012, dari jumlah buruh Indonesia yang mencapai 112 juta orang, sebanyak 43 juta diantaranya adalah buruh perempuan (Rini, 2015). Data lain mengemukakan terdapat 80.000 orang kaum buruh pada sektor manufaktur di Jakarta, dan 90 persen di antaranya adalah perempuan (Kompas, 2013). Data BPS tahun 2009 menunjukkan bahwa sebanyak 75,69 persen buruh perempuan usia 15 tahun ke atas hanya berpendidikan tamat SMP ke bawah, di mana perempuan yang hanya mengenyam pendidikan hingga tingkat SD mencapai 30,70 persen. Lalu semakin tinggi tingkat pendidikan, persentase partisipasi pendidikan perempuan semakin rendah, yaitu SMA (18,59 persen), Diploma (2,74 persen), dan Universitas (3,02 persen). Namun hingga saat ini peneliti belum memperoleh data berapa jumlah buruh perempuan yang telah menikah dan memiliki anak.

Jabodetabek, sebagai barometer perekonomian Indonesia memiliki Upah minimum tahun 2015 sebagai berikut: $\mathrm{Rp}$ 2.693.000,- (Jakarta); Rp 2.658.155,(Bogor); Rp 2.705.000,- (Depok); Rp 2.710.000,- $\quad$ (Tangerang); dan $\quad \mathrm{Rp}$ 2.954.031,- (Bekasi). Tingkat upah yang ditawarkan walaupun dirasa cukup ataupun kurang adalah relatif bagi masing-masing buruh, namun kebutuhan akan pendapatan yang lebih tinggi membuat pekerjaan selaku buruh selalu diminati dari waktu ke waktu, selain itu untuk menjadi buruh tidak 
dibutuhkan tingkat keterampilan dan pendidikan yang tinggi.

Hingga saat ini budaya di masyarakat kita menganut anggapan sosial bahwa dalam rumah tangga, laki-laki selaku kepala keluarga dan suami adalah pencari nafkah, dan perempuan, sebagai istri mengurusi urusan rumah tangga. Namun kondisi ketika penghasilan suami dirasa kurang untuk mencukupkan kebutuhan rumah tangga, tak ayal mengakibatkan perempuan ikut bekerja di luar rumah. Dan pekerjaan yang mudah didapat untuk mereka yang berpendidikan rendah dan tidak membutuhkan keterampilan terlalu tinggi adalah bekerja sebagai buruh.Kondisi menjadi relevan dengan motivasi buruh perempuan dalam bekerja, dimana pada umumnya mereka terdorong oleh berbagai kebutuhan seperti teori hirarki kebutuhan oleh Maslow tahun 1960 an sampai 1970an dalam Robbins, 2014.p.533. Namun dalam hal ini buruh wanita diduga lebih didominasi kebutuhan fisiologis yang diharapkan dapat mendukung kehidupan yang lebih layak. Sementara itu untuk dapat hidup layak dan berkualitas para buruh di
Jabotabek masih jauh dari kondisi baik bila diukur berdasarkan standard kualitas hidup dunia dimana Indonesia menempati peringkat ke 140 bahkan di bawah beberapa negara Asia Tenggara lainnya. Kualitas hidup bangsa Indonesia terutama bila dilihat dari kondisi eknomi masih cukup rendah dibanding negara-negara Asia Tenggara dimana dari angka indeks kemiskinan Indonesia berada dibawah Singapura, Malaysia, Thailand, Philipine, bahkan Vietnam (UNDP, 2006 dalam Widiyanto)

Bekerja sebagai buruh perempuan tidak selalu nyaman dan layak. Namun, tuntutan untuk membantu suami memenuhi kebutuhan rumah tangga ini membuat buruh perempuan tetap bertahan dalam pekerjaannya, inilah yang disebut dengan komitmen kontinuans. Erben dan Guneser (2008) mengutip definisi commitment continuance dari Meyer dan Allen (1991) yang menyatakan bahwa "continuance commitment occurs as a result of awareness of the cost associated with leaving the organization", yaitu buruh perempuan tetap memilih bekerja untuk memperoleh 
penghasilan walaupun mungkin dia tidak secara emosi melekat pada perusahaan tempat kerja, atau bahkan mungkin ia sendiri tidak betah bekerja di pabrik dan sebenarnya ingin keluar dari pekerjaan. Namun upah yang didapat terlebih lagi jika digabung dengan upah yang diperoleh dari penghasilan suaminya akan dapat memenuhi kebutuhan rumah tangga dan meningkatkan kualitas hidupnya (quality of life), ini terlihat dari fenomena di sekitar kita banyak para buruh yang tercukupkan sandang, pangan serta hunian, membeli motor, dapat berekreasi dan memiliki tabungan, serta dapat membiayai pendidikan dan biaya kesehatan anakanaknya.

Penelitian ini berusaha untuk mendapatkan gambaran komprehensif mediasi komitmen kontinuans dan moderasi dukungan organisasi dan serikat pekerja Indonesia dalam pengaruh motivasi terhadap quality of life pekerja perempuan yang telah menikah dan memiliki anak di industri manufaktur di Jabotabek. Kemudian juga untuk mendapatkan gambaran komprehensif mediasi komitmen kontinuans dan moderasi dukungan pemerintah dalam bentuk Undang-Undang seperti UU 13/2003 tentang Ketenagakerjaan, UU 21/2000 tentang serikat pekerja/serikat buruh, dan UU no. 2/2004 dalam pengaruh motivasi terhadap quality of life. Moderasi dukungan pemerintah dan serikat pekerja Indonesia dalam pengaruh komitmen kontinuans terhadap quality of life juga akan diuji dalam riset ini.

\subsection{Rumusan Masalah}

Masalah penelitian ini adalah bagaimana motivasi dapat meningkatkan kualitas hidup responden melalui komitmen kontinuans dan dukungan organisasi, Pemerintah dan serikat pekerja.

Pertanyaan penelitian:

1. Apakah motivasi berpengaruh signifikan terhadap Quality of Life?

2. Apakah motivasi berpengaruh signifikan terhadap komitmen kontinuans?

3. Apakah komitmen kontinuans berpengaruh signifikan terhadap Quality of Life? 
4. Apakah praktek dukungan organisasasi (PDO) dapat memoderasi pengaruh motivasi terhadap komitmen kontinuans?

5. Apalah PDO dapat memoderasi pengaruh motivasi terhadap Quality of Life?

6. Apakah dukungan serikat pekerja Indonesia (DSPI) dapat memoderasi pengaruh motivasi terhadap komitmen kontinuans?

7. DSPI dapat memoderasi pengaruh motivasi terhadap Quality of Life?

8. Apakah dukungan pemerintah (DP) dapat memoderasi pengaruh komitmen kontinuans terhadap Quality of Life?

9. Apakah DP dapat memoderasi pengaruh motivasi terhadap Quality of Life?

10. Apakah DSPI dapat memoderasi pengaruh komitmen kontinuans terhadap Quality of Life?

\subsection{Tujuan Penelitian}

a. Untuk mendapatkan gambaran komprehensif moderasi

Dukungan Organisasi,
Pemerintah, dan Serikat Pekerja pada pengaruh motivasi yang dimediasi komitmen kontinuans terhadap kualitas hidup pekerja perempuan di industri manufaktur di Jabotabek.

b. Untuk mendapatkan gambaran komprehensif mediasi komitmen kontinuans dan moderasi dukungan pemerintah dan serikat pekerja Indonesia dalam pengaruh motivasi terhadap quality of life pekerja perempuan yang telah menikah dan memiliki anak di industri manufaktur di Jabotabek.

c. Untuk mendapatkan gambaran komprehensif moderasi dukungan pemerintah dan serikat pekerja Indonesia dalam pengaruh komitmen kontinuans terhadap quality of life pekerja perempuan yang telah menikah dan memiliki anak di industri manufaktur di Jabotabek.

d. Menemukan berbagai faktor yang perlu direkomendasikan 
Analisis Dukungan Organisasi ... (Sylvia D., Christine W., dan Benedicta E.)

untuk diperhatikan oleh mengenai kondisi pekerja perempuan perusahaan, SPI maupun dalam motivasi dan komitmen kontinuans, Pemerintah untuk meningkatkan peran dukungan organisasi,SPI dan juga kualitas hidup pekerja Pemerintah dalam memoderasi pengaruh perempuan yang telah menikah motivasiterhadap quality of life yang dan memiliki anak di Indonesia. dimediasi komitmen kontinuans.Ibu adalah wanita yang mengemban peran reproduktif

\subsection{Urgensi Penelitian}

Fenomena maraknya demonstrasi para buruh di Jabotabek maupun di luar Jabotabek untuk meminta kenaikan upah minimum merupakan indikator masih rendahnya kualitas hidup para buruh di Indonesia. Sementara sulitnya kesempatan untuk mendapatkan pekerjaan membuat para buruh tidak punya pilihan lain selain bertahan dengan kondisi pekerjaan yang ada. Namun demikian, penelitian yang mengangkat issue tersebut masih relative sedikit dilakukan di Indonesia.konkrit.

Mengingat pentingnya peran pekerja perempuan dalam kehidupan keluarga, kelangsungan organisasi mencapai tujuannya dan juga penentu kualitas generasi muda penerus bangsa maka penelitian ini menjadi sangat penting. Penelitian ini akan memberi gambaran dan domestik yang tidak tergantikan oleh siapapun. Karena di tangan seorang Ibu yang hidupnya berkualitas akan tumbuh anak-anak yang cerdas, sehat dan berkualitas.

Penelitian sebelumnya yang secara khusus mengangkat isu tentang pekerja perempuan di industri manufaktur yang telah menikah dan memiliki anak, hingga saat ini belum penulis dapatkan. Namun menurut peneliti, penelitian ini menjadi penting pada masa kini dan dapat memberikan masukan berharga bagi pemerintah, perusahaan, dan serikat pekerja. Mengenai komitmen, secara khusus peneliti mengangkat tentang masalah komitmen kontinuans, karena bagi peneliti kepedulian utama mengapa perempuan dengan pendidikan rendah dan telah menikah dan memiliki anak masuk ke 
dunia kerja sebagai buruh di industri manufaktur adalah karena kebutuhan keuangan guna membantu meningkatkan penghasilan keluarga dari apa yang dihasilkan oleh suami.

\section{TINJAUAN PUSTAKA}

\subsection{Kualitas Hidup (Quality of Life/QoL)}

Quality of life didefinisikan oleh World Health Organization (WHO) sebagai penilaian individu atas kualitas hidup manusia dan persepsi seseorang atas kehidupannya di bawah pengaruh sistem nilai budaya dari kondisi dimana seseorang hidup (Darvish-Poor Kakhaki, et., al., dalam Bano, et., al., 2015) Quality of life mengacu pada kesejahteraan individu dan masyarakatnya secara umum. Indikator quality of life mencakup faktor-faktor yang tidak hanya fokus pada uang dan pekerjaan, tetapi juga sekelilingnya, lingkungan, kesejahteraan fisik dan mental, pendidikan, waktu luang, dan relasi sosial (Bano, et., al., 2015). Sedangkan menurut Diener et al.1999; Greenley et al.1997 dalam Cheung dan Leung (2010), quality of life mengacu pada evaluasi seseorang terhadap kondisi kehidupan, yang diterapkan dalam kehidupan individu, quality of life terdiri atas kehidupannya di pekerjaan, waktu luang, keuangan, dan kehidupan sosial.

$$
\text { Inoguchi dan Fujii }
$$
menganalisis quality of life di Jepang dari 16 bidang yaitu: 1) perumahan; 2) pertemanan; 3) pernikahan; 4) standar hidup; 5) pendapatan rumah tangga; 6) kesehatan; 7) pendidikan; 8) pekerjaan; 9) hubungan dengan tetangga; 10) keamanan publik; 11) kondisi lingkungan; 12) sistem kesejahteraan sosial; 13) sistem demokrasi; 14) kehidupan keluarga; 15) waktu luang; dan 16) kehidupan spiritual. Namun di dalam penelitiannya mereka mendapatkan bahwa menikah dan kepuasan terhadap kehidupan pernikahan mempengaruhi quality of life di Jepang.

Di Indonesia quality of lifemasih mengacu kepada Human Development Index (HDI) yang ditetapkan WHO seperti kesehatan fisik, kesehatan psikologis, hubungan sosial dan lingkungan (Skevington, et al. 2004). Rendahnya tingkat kualitas hidup di Indonesia 
Analisis Dukungan Organisasi ... (Sylvia D., Christine W., dan Benedicta E.)

mendorong Pemerintah untuk terus mutu pendidikan antar wilayah; 4) Hak atas menaikkan Indeks Pembangunan Manusia rasa aman: berkurangnya ketegangan Indonesia (IPM) melalui konsep social, kejadian konflik komunal, korban Pembangunan Manusia Indonesia yang perdaganagan manusia akibat bencana, kemudian diterjemahkan dalam Rencana ancaman terhadap peluang kerja dan Aksi Nasional Pembangunan Manusia berusaha; 5) Hak atas wawasan kebangsaan Indonesia yaitu: 1) Hak atas pangan : Dari beberapa kriteria kualitas hidup berkurangnya kejadian rawan pangan, busung lapar gizi kurang pada balita menjadi $20 \%$ serta kemandirian pangan di tingkat kabupaten/kota; 2) Hak atas kesehatan, membaiknya akses masyarakat miskin terhadap pelayanan kesehatan, menurunnya angka kematian ibu kurang dari 226/100.000 kelahiran, meningkatnya angka pertolongan persalinan oleh tenaga kesehatan menjadi 90\%, menurunnya angka kematian bayi dan balita menjadi $25 \%$, meningkatnya perilaku hidup bersih dan sehat, menurunnya angka pravalensi HIV/AIDS, malaria dan TBC; 3) Hak atas pendidikan: penuntasan Wajar Diknas 9 tahun, menurunnya jumalh BA usia 15 tahun ke atas menjadi 5\%, peningkatan APS menengah atas dan kejuruan laki-laki dan perempuan dari keluarga miskin menjadi 35 $\%$ dan 28,5 \% pengurangan kesenjangan

\subsection{Komitmen Kontinuans (continuance commitment /CC)}

Terdapat banyak definisi komitmen organisasi. Namun definisi yang paling banyak dikutip adalah definisi menurut Allen dan Meyer, 1990 (dalam Erben dan 
Guneser, 2008), yaitu a psycological state that binds the individual to the organization. Allen dan Meyer mendefinisikan komitmen organisasi sebagai konstruk multidimensional yang terdiri atas tiga tipe komitmen organisasi yang berbeda, yaitu: komitmen afektif (affective commitment), normatif (normative commitment), dan kontinuans (continuance commitment). Komitmen afektif adalah perasaan dimana karyawan melekat secara emosi pada organisasi, mengidentifikasikan diri dan terlibat di dalam organisasi. Komitmen normatif didefinisikan sebagai perasaan sebagai suatu keharusan untuk tetap bekerja di organisasi. Sedangkan komitmen kontinuans terjadi sebagai hasil dari kesadaran akan biaya yang terjadi akibat meninggalkan organisasi. Setiap tipe komitmen dianggap berkontribusi terhadap relasi karyawan di dalam organisasi, dan memiliki implikasi untuk melanjutkan keanggotaannya di dalam organisasi dan dapat dipengaruhi oleh berbagai antecedent atau memiliki konsekuensi berbeda.Komitmen kontinuans adalah keinginan untuk tetap tinggal di dalam organisasi karena investasi yang karyawan miliki dan juga investasi yang "nontransferable" (seperti pensiun, relasi dengan karyawan lain, atau hal lainnya yang istimewa dalam organisasi (Reichers, 1985 dalam Bano, et., al, 2015). Karyawan merasa lebih melekat dan berkomitmen pada organisasi jika mereka merasa bahwa organisasi mendukung (organizational support), menyemangati ethical conduct, dan berlaku sebaliknya terhadap unethical conduct (Trevino, et., al (1998) dalam Erben dan Guneser (2008).

Komitmen organisasional memiliki tiga komponen yang saling terkait, yaitu: 1) kebanggaan terhadap organisasi dan internalisasi terhadap tujuannya; 2) keinginan untuk menginvestasikan usahausaha pribadinya demi organisasi; dan 3) afeksi terhadap dan melekat pada organisasi dan berharap untuk tetap menjadi anggota organisasi. Korelasi komitmen organisasi dapat dikelompokkan ke dalam 3 kategori mayor: a) karakteristik pribadi (usia, masa kerja, pendidikan, locus of control); b) peran/karakteristik pekerjaan (konflik 
peran, ambiguitas peran, umpan balik, dan kesempatan promosi) dan masalah di identitas tugas, dan variasi pekerjaan); c) luar pekerjaan seperti hal-hal yang karakteristik organisasi (komunikasi, melibatkan kaitan dengan komunitas dan kesempatan berkembang dan promosi, grup penyesuaian yang harus dilakukan oleh kohesivitas, pelatihan, job security, keluarga karyawan bila ia meninggalkan tunjangan finansial, apresiasi dan pekerjaannya, (Powell \&Meyer (2004). pengakuan, obyektifitas dan rasionalitas, penanganan keluhan, relasi dengan penyelia dan kepercayaan satu sama lain, kepemimpinan supportif/partisipatif, standardisasi, desentralisasi, formalisasi dan ketergantungan fungsional, fasilitas kesejahteraan, dan kesejahteraan korporasi (Cook \& Wall, 1980 dalam Sharma (1997),

Bagaimanapun komitmen akan mengurangi terjadinya turnover,bahwa komitmen kontinuans melibatkan dua dimensi, yaitu karena kurangnya kesempatan kerja (lack of employment opportunities) dan pengorbanan yang dipersifikasikan dari investasi dikaitkan bila meninggalkan organisasi (Mc Gee \& Ford 1987 dalam Taing et al, 2011). Lebih lanjut dinyatakan pula, pengorbanan yang dipersifikasikan dari investasi dikaitkan dengan pengaturan birokrasi (mencakup isu ekonomi seperti pembayaran, tunjangan,

\subsection{Motivasi (MOT)}

Motivation is the set of forces that leads people to behave in particular way (Moorhead dan Griffin, 2010). Seperti halnya apa yang dinyatakan Maslow dalam teori hirarki kebutuhan bahwa seseorang akan selalu memenuhi kebutuhan fisiologis dan rasa aman terlebih dahulu baru kemudian kebutuhan social, esteem dan aktualisasi. Desakan kebutuhan untuk dapat memenuhi kebutuhan ekonomi membuat para buruh wanita ini tetap bekerja meskipun menghadapi life complexity and dynamic yang tinggi. Teori motivasi pada dasarnya dibagi dalam 2 kategori yaitu content theories dan process theories. Teori Maslow, 1954 dan beberapa teori kebutuhan lainnya seperti teori Alderfer, 1972; Hezberg, 1959 dan Mc Clleland 1961 adalah contoh content theories, sedangkan 
teori-teori lain seperti teori equity oleh job stress (Thompson \& Prottas, 2005). Hal Adams, teori harapan Vroom, 1964 ini menjadi issue penting yang sering merupakan contoh teori proses (Robbins, diabaikan, khususnya di Indonesia. 2014, p.533-544). Dalam konten teori Organisasi sebagai pihak pemberi kerja dinyatakan bahwa seseorang akan terus sudah semestinya memperhatikan terdorong bertindak karena adanya karyawan dengan menyediakan fasilitas dorongan kebutuhan yang mendesak

\subsection{Praktek Dukungan Organisasi (PDO)}

Tingginya komitmen karyawan terhadap organisasi seringkali dikaitan dengan bagaimana organisasi memberi dukungan terhadap karyawan sebagai anggota organisasi. Perceived organizational support mengacu pada keyakinan karyawan terhadap tingkat dimana organisasi menilai kontribusi mereka dan peduli terhadap kesejahteraan mereka secara umum (Eisenberger et al., 1986; Rhoades et al., 2001 dalam Taing, et., $\mathrm{al}, 2011)$.

Dukungan organisasi dapat diberikan dalam berbagai program baik secara formal (family friendly policies) maupun informal (seperti dukungan rekan kerja atau supervisor) dapat menurunkan

\subsection{Dukungan Serikat Pekerja Indonesia (DSPI)}

Serikat pekerja

(union)

didefinisikan sebagai 'formal association of workers that promotes the interests of its members through collective action' (Lim, et., al., 2010). Secara individu, karyawan hanya dapat melepaskan relatif lebih sedikit kekuasaan dalam relasinya dengan perusahaan. Berbagai penelitian mengenai mengapa karyawan berserikat banyak datang dari studi mengenai karyawan berkerah biru di sektor swasta. Studi ini secara umum menyimpulkan bahwa karyawan berserikat sebagai hasil dari kebutuhan ekonomi, ketidakpuasan dengan praktek manajerial, dan atau sebagai cara 
untuk memenuhi kebutuhan dan status sosialnya. Singkatnya, karyawan melihat serikat pekerja sebagai salah satu cara untuk mencapai hasil yang tidak dapat mereka capai jika mereka bertindak secara individu. Sedangkan alasan mendasar mengapa perusahaan menolak karyawannya berserikat adalah karena: 1) studi memperlihatkan bahwa tunjangan dan upah menjadi lebih tinggi di organisasi yang memiliki serikat pekerja dibandingkan dengan organisasi dengan bidang yang sama namun tidak memiliki serikat pekerja; 2) serikat pekerja memiliki dampak signifikan pada hak prerogatif manajemen dalam membuat keputusan mengenai karyawan; dan 3) serikat pekerja membatasi kebebasan manajemen untuk memformulasikan kebijakan unilateral SDM dan capat menantang otoritas penyelia (Bohlander and Snell, 2013). Penelitian yang dilakukan oleh Jarrel dan Stanley (1990) sebagaimana dikutip oleh Milkovich, et., al (2014) menemukan bahwa ringkasan dari analisis atas 114 studi yang berbeda menyimpulkan bahwa perbedaan upah dari yang berserikat dan tidak berserikat adalah: 1) serikat pekerja membuat perbedaan dalam upah, hampir di semua studi dan di seluruh periode waktu; 2) Ukuran kesenjangan berbeda dari tahun ke tahun, dimana dalam periode tingkat pengangguran tinggi, dampak serikat pekerja lebih besar. Dalam kondisi ekonomi kuat, kesenjangan serikat dan tidak berserikat lebih kecil.

\subsection{Dukungan Pemerintah (PD)}

Di Indonesia hubungan serikat pekerja, termasuk pula hak dan kewajibannya dengan perusahaan dan juga dengan pemerintah diatur dalam UndangUndang 13/2003 tentang Ketenagakerjaan, Undang-Undang 21/2000 tentang Serikat Pekerja/Serikat Buruh, dan UndangUndang no. 2/2004 tentang Penyelesaian Perselisihan Hubungan Industrial. Dukungan pemerintah menjadi penting dalam menfasilitasi hubungan yang terkadang tidak seimbang antara pengusaha dan buruh.

Beberapa dukungan pemerintah terhadap tenaga kerja yang diatur dalam Undang-Undang diantaranya adalah 
mengenai kesempatan kerja yang sama (tanpa diskriminasi), pelatihan kerja, penempatan tenaga kerja, perluasan kesempatan kerja, penggunaan tenaga kerja asing, hubungan kerja, perlindungan terhadap penyandang cacat, pekerja anak dan perempuan, waktu kerja, keselamatan dan kesehatan kerja (K3), masalah pengupahan, kesejahteraan, pemutusan hubungan kerja, karyawan mengundurkan diri dan pensiun, perusahaan tutup, cacat karena celaka pekerjaan, dan karyawan meninggal dunia.

\subsection{Hipotesis dan Model Penelitian}

Hirarki kebutuhan dalam teori Maslow dapat pula dikaitkan dengan bagaimana pemenuhan kebutuhan dalam kehidupan seseorang secara bertahap yang akhirnya relevan dengan gambaran kualitas hidup yang dirasakan (Clarke and Islam, 2004). Dalam banyak diskusi cakupan kualitas kehidupan dapat dipandang dalam lingkup yang luas yang meliputi kebutuhan dan keinginan. Hal ini juga relevan dengan penelitian Ingram, Lee \& Skinner, 1989 yang menyatakan bahwa motivasi dan komitmen merupakan faktor dari usaha dalam meningkatkan kinerja.

Maslow mengembangkan teorinya untuk penerapan diluar psikologi, disamping itu beberapa riset telah diperluas untuk tujuan pengembangan dan isue kualitas hidup dalam kaitan yang kuat dalam pemahaman antara human motivation dan quality of life, (Hagerty 1999 dan Sirgy 1986 dalam Lazim \& Osman 2009). Beberapa temuan riset antara lain yang dilakukan Wittmer, 1991; Moon, 2000 juga menyatakan faktor ekstrinsik seperti reward (imbalan) masih menjadi faktor motivasi yang tinggi bahkan pada level manajer sekalipun. Dengan demikian motivasi karyawan dalam bekerja dapat menjadi faktor yang meningkatkan komitmen kontinuan dan selanjutnya dapat meningkatkan kualitas hidup terutama pada buruh perempuan yang pada umumnya bekerja untuk meningkatkan penghasilan keluarga dalam memenuhi kebutuhan hidup.

Penelitian-penelitian sebelumnya banyak mengemukakan bahwa perceived organizational support sebagai antecedent 
terhadap commitment (Bishop and Scott, 2000; Liden, et al., 2003). Hal ini mendesak khususnya bagi karyawan wanita dengan peran gandanya. Selain dukungan yang diberikan dalam bentuk program yang berkaitan dengan work family conflict, dukungan lainnya tentu menjadi sangat penting terutama yang berkaitan dengan harapan karyawan untuk mensejahterakan kehidupannya. Menurut teori dukungan organisasi, perceived organizational support merupakan manfaat yang diberikan organisasi yang layak akan balasan atau timbal balik dari karyawan. Salah satu cara dimana karyawan akan membalasnya adalah dengan memberikan komitmen mereka terhadap organisasi (Eisenberger, et., al, 1986 dalam Taing, et., al, 2011). Namun, berbeda dengan temuan Purba, 2013 yang menguji pengaruh dukungan organisasi terhadap intention to stay pada karyawan wanita yang bekerja di Bank di Jakarta, ternyata dukungan organisasi tidak signifikan berpengaruh terhadap keinginan untuk tinggal di perusahaan.

Ide mendasar untuk mengukur kesuksesan atau kesejahteraan serikat pekerja adalah melalui tingkat dimana tujuan kerja dan tingkat upah adalah memuaskan di suatu negara, dibandingkan dengan negara lain yang menjadi referensi. Serikat pekerja biasanya memiliki tujuantujuan, yang kepentingannya berbeda di antara serikat pekerja lainnya. Tujuan yang terutama adalah terkait kompensasi dan pekerjaan dari para anggota serikat pekerja. Tujuan lainnya adalah kepedulian mereka mengenai tingkat dan penjadwalan jam kerja, tingkat keamanan dari tindakan arbitrase penyelia, tingkat dimana para pekerja berpartisipasi dalam membentuk lingkungan kerja mereka sendiri, kondisi kerja, tunjangan moneter selain upah, dan lain-lain. Indikator dari kesejahteraan atau keberhasilan serikat pekerja fokusnya pada hasil (outcomes) dan bukan pada proses (Pencavel, 2009).

Sebagai buruh yang bekerja di industri manufaktur biasanya para buruh wanita ini menjadi anggota serikat pekerja dengan harapan kehadiran serikat pekerja ini dapat memperjuangkan hak-hak kaum buruh. Kesuksesan peran serikat pekerja dalam meningkatkan kesejahteraan 
anggotanya menjadi penting dan telah pemerintah federal Amerika Serikat banyak dirasakan di negara-negara maju mengambil tindakan baik untuk melindungi seperti US (Pencavel, 2009). Peningkatan maupun merintangi pekerja, (Adler, (2006) kualitas hidup kaum buruh dapat didukung kehadiran serikat pekerja.

Penelitian yang dilakukan oleh Jarrel dan Stanley (1990) sebagaimana dikutip oleh Milkovich, et., al (2014) menemukan bahwa ringkasan dari analisis atas 114 studi yang berbeda menyimpulkan bahwa perbedaan upah dari yang berserikat dan tidak berserikat adalah: 1) serikat pekerja membuat perbedaan dalam upah, hampir di semua studi dan di seluruh periode waktu; 2) Ukuran kesenjangan berbeda dari tahun ke tahun, dimana dalam periode tingkat pengangguran tinggi, dampak serikat pekerja lebih besar. Dalam kondisi ekonomi kuat, kesenjangan serikat dan tidak berserikat lebih kecil.

Masyarakat memiliki cara yang berbeda dalam memandang peran yang harus dimainkan pemerintah untuk melaksanakan kebijakan publik yang melindungi kepentingan-kepentingan karyawan (Kaufman, 2000 dalam Milkovich, 2014). Selama bertahun-tahun, dalam Lim (2010).Saat ini di Amerika Serikat Undang-Undang mengatur relasi buruh untuk menciptakan lingkungan dimana baik pengusaha maupun serikat pekerja, masing-masing dapat melaksanakan hak dan kewajibannya.Hal ini sesuai dengan teori ekuitas atau keadilan yang dikemukakan oleh Adams, 1965 dimana dinyatakan prinsip keadilan berkaitan dengan persepsi seseorang dengan keyakinan atas hasil yang diterima. Orang-orang yang terlibat dalam proses subjektif menentukan apakah hasil atau tidak didasarkan pada perhitungan masukan seseorang atas hasil dan kemudian membandingkan rasio ini dengan perbandingan lainnya. Keadilan distributif dengan fokus pada hasil diperkirakan berhubungan dengan kognitif, afektif dan reaksi perilaku untuk hasil yang spesifik, (Cohen et al. 2001)

Dari uraian riset-riset terdahulu dan teori-teori terkait maka dalam penelitian ini disajikan 3 Model penelitian. Pada Model 1 


\section{Analisis Dukungan Organisasi ... (Sylvia D., Christine W., dan Benedicta E.)}

akan diuji pengaruh Motivasi terhadap Quality of Life yang dimediasi Continuance Commitment dimana secara internal Praktek Dukungan Organisasi (PDO) dan Dukungan Serikat Pekerja Indonesia (DSPI) dapat memperkuat pengaruh Motivasi terhadap Continuance Commitment dan Quality of Life. Dalam Model 1 ini diasumsikan bahwa Dukungan organisasi dapat menjadi faktor pertimbangan bagi karyawan untuk berkomitmen disamping dukungan serikat pekerja yang ada dalam organisasi sebagai pihak yang membela hak-hak buruh terhadap organisasi. Berikut disajikan Model 1.
Model 1: Mediasi Komitmen Kontinuans dan moderasi Dukungan Organisasi dan SPI dalam pengaruh Motivasi terhadap Kualitas Hidup

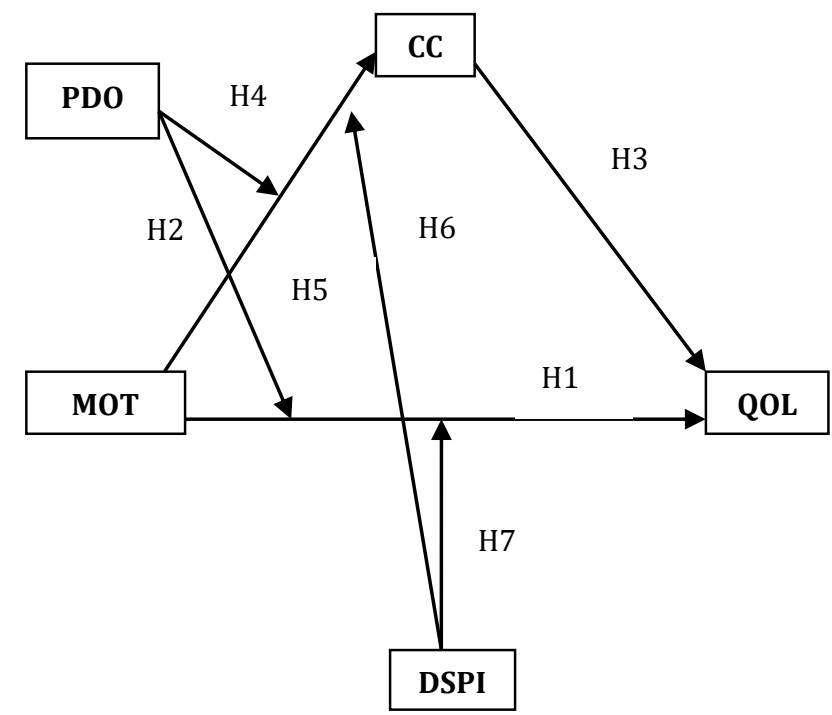

Sumber: Hasil olahan untuk penelitian

H1: Motivasi berpengaruh signifikan terhadap kualitas hidup

H2: Motivasi berpengaruh signifikan terhadap komitmen kontinuans

H3: Komitmen organisasi berpengaruh signifikan terhadap kualitas hidup

H4: PDOdapat memoderasi pengaruh

Motivasi terhadap komitmen kontinuans

H5: PDO dapat memoderasi pengaruh Motivasi terhadap Quality of Life 
H6: DSPI dapat memoderasi pengaruh Motivasi terhadap komitmen kontinuans

H7: DSPI dapat memoderasi pengaruh Motivasi terhadap Quality of Life

Model berikutnya disajikan untuk menguji apakah Pemerintah dan Serikat Pekerja sebagai pihak di luar organisasi dapat memberi dukungan pada efek motivasi buruh perempuan terhadap kualitas hidup melalui komitmen kontinuans.Dalam Model 2 pengujian dilanjutkan dengan meneliti apakah secara eksternal Dukungan Pemerintah dan Dukungan Serikat Pekerja dapat memperkuat pengaruh Motivasi terhadap Quality of Life dan pengaruh Continuance Commitment terhadap Quality of Life. Pada Model 2 ini disumsikan secara eksternal melalui peraturan dan perundang-undangan Pemerintah dan Serikat Pekerja dapat mendorong Continuance Commitment yang dimiliki karyawan untuk meningkatkan Quality of Life dimana Serikat Pekerja ikut menyuarakan pembelaan terhadap hak-hak buruh. Model 2 disajikan sebagai berikut:
Model 2: Mediasi Komitmen dan moderasi

Dukungan Pemerintah dan SPI dalam pengaruh Motivasi terhadap Kualitas Hidup

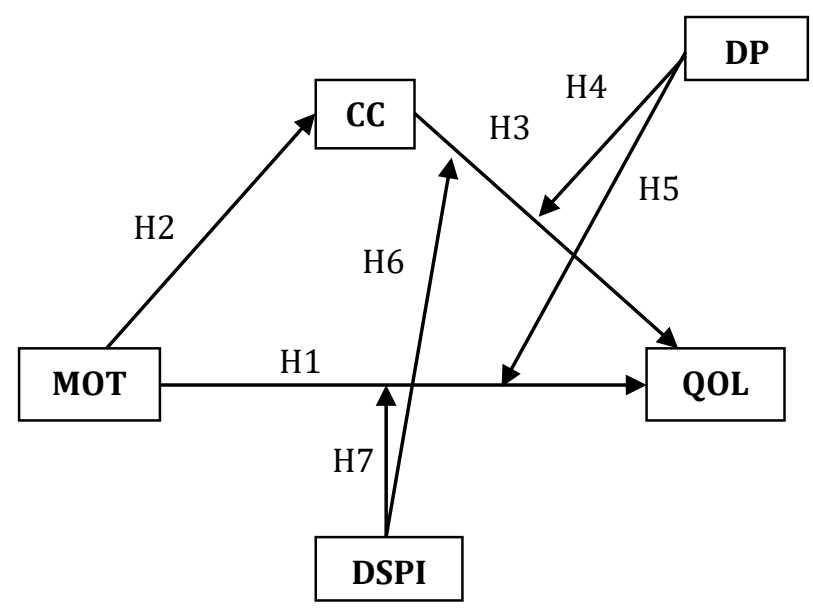

Sumber: Hasil olahan untuk penelitian

H1: Motivasi berpengaruh signifikan terhadap kualitas hidup

H2: Motivasi berpengaruh signifikan terhadap komitmen kontinuans

H3: Komitmen organisasi berpengaruh signifikan terhadap kualitas hidup

H4: DP dapat memoderasi pengaruh komitmen kontinuans terhadap kualitas hidup

H5: DP dapat memoderasi pengaruh motivasi terhadap Quality of Life

H6: DSPI dapat memoderasi pengaruh komitmen kontinuans terhadap kualitas hidup 
H7: DSPI dapat memoderasi pengaruh Motivasi terhadap Quality of Life

Analisis yang terakhir dilakukan terhadap model dimana komitmen kontinuans berpengaruh terhadap kualitas hidup. Dengan mengeluarkan variabel motivasi dan praktek dukungan organisasi, maka model ini menguji apakah peranan pemerintah dan serikat pekerja secara bersama-sama dapat memperkuat pengaruh komitmen buruh perempuan untuk tetap bekerja di pabriknya terhadap peningkatan kualitas hidup mereka. Berikut adalah model 3.

Model 3: Moderasi Dukungan Pemerintah dan Serikat Pekerja Indonesia pada Pengaruh Komitmen Kontinuans terhadap Kualitas Hidup

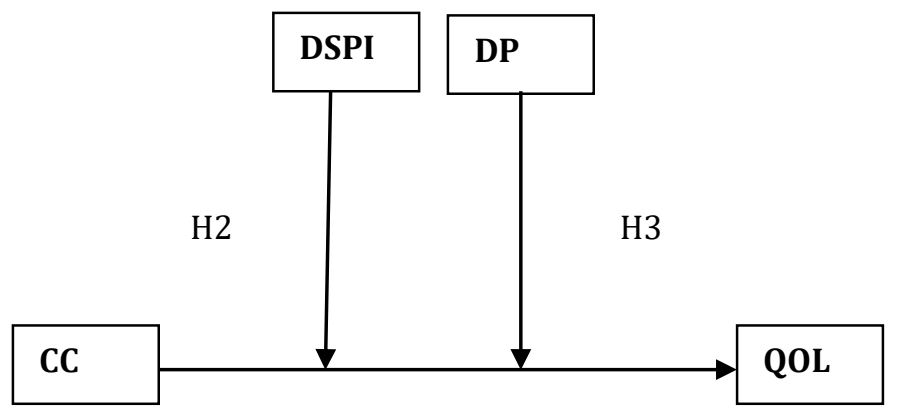

$\mathrm{H} 1$

Sumber: Hasil olahan untuk penelitian
H1: Komitmen kontinuans berpengaruh signifikan terhadap kualitas hidup

H2: Dukungan Serkat Pekerja dapat memoderasi pengaruh komitmen kontinuans terhadap kualitas hidup

H3: Dukungan Pemerintah dapat memoderasi pengaruh komitmen kontinuans terhadap kualitas hidup

\section{METODE PENELITIAN}

\subsection{Definisi Operasional}

Definisi operasional variabel dalam penelitian ini adalah sebagai berikut:

- Quality of life adalah penilaian individu atas kualitas hidup manusia menurut konsep tingkatan, terangkum secara kompleks mengacu kepada Human Development Index (HDI) yang ditetapkan WHO seperti kesehatan fisik, kesehatan psikologis, hubungan sosial dan lingkungan (Skevington, et al. 2004).

- Komitmen Kontinuans adalah komitmen yang terjadi sebagai hasil dari kesadaran akan biaya yang terjadi akibat meninggalkan 
organisasi. (Allen dan Meyer, 1990 dalam Erben dan Guneser, 2008).

- Motivasi adalah seperangkat tekanan yang membawa individu untuk berperilaku dalam cara tertentu (Moorhead dan Griffin, 2010). Dalam penelitian ini motivasi diukkur dengan menggunakan hirarki kebutuhan Maslow.

- Praktek dukungan organisasi adalah keyakinan karyawan terhadap tingkat dimana organisasi menilai kontribusi mereka dan peduli terhadap kesejahteraan mereka secara umum (Eisenberger et al, 1986; Rhoades, et al., 2001 dalam Taing et al, 2011).

- Serikat pekerja (union) adalah asosiasi formal dari para pekerja yang meningkatkan minat-minat dari anggotanya melalui tindakan kolektif (Lim et al., 2010). Dukungan Serikat Pekerja adalah peran serikat pekerja untuk meningkatkan minat-minat dari anggotanya.
- Dukungan Pemerintah adalah tindakan yang diambil pemerintah baik untuk melindungi maupun merintangi pekerja terkait hak-hak dan kewajibannya (Adler 2006) dalam Lim (2010).

\subsection{Data dan Pengukuran}

Data dikumpulkan dalam bentuk kuesioner dengan item yang telah disesuaikan dengan kondisi pekerja sebagai buruh seperti berikut ini.

Populasi penelitian ini adalah buruh perempuan di Jabotabek yang telah menikah dan mempunyai anak. Sulit untuk menghitung jumlah populasi dalam penelitian ini, sehingga penelitian dilakukan dengan tehnik convenience sampling. Kuesioner disebar ke daerahdaerah pemukiman buruh yang berada di wilayah Jakarta, Bogor, Tangerang, Depok, dan Bekasi masing-masing 50 eksemplar kuesioner. Dari 250 kuesioner yang disebar hanya 126 kuesioner yang layak digunakan karena banyak kuesioner yang tidak kembali dan yang tidak lengkap. 
Analisis Dukungan Organisasi ... (Sylvia D., Christine W., dan Benedicta E.)

Tabel 3.1 : Item kualitas hidup (quality of life/QoL)

\begin{tabular}{|l|l|}
\hline NO & PERNYATAAN \\
\hline & Sandang Pangan dan Hunian \\
\hline 1 & Dengan bekerja keluarga saya dapat memenuhi kebutuhan makanan yang sehat. \\
\hline 2 & $\begin{array}{l}\text { Saat ini keluarga saya tinggal di rumah yang layak dan luasnya cukup untuk jumlah } \\
\text { penghuni (ada kamar mandi/wc, ventilasi, kamar tidur, dapur ) }\end{array}$ \\
\hline 3 & $\begin{array}{l}\text { Keluarga saya dpt memenuhi kebutuhan hidup sehari-hari sesuai kebutuhan (air bersih, } \\
\text { listrik, pakaian, peralatan mandi \& kebersihan rumah)*coret yg tdk ada }\end{array}$ \\
\hline & Pendidikan dan Kesehatan \\
\hline 4 & Anak-anak saya dapat bersekolah sesuai usia sekolah \\
\hline 5 & Di rumah, saya memiliki tv dan atau radio \\
\hline 6 & Saya sering membaca koran/tabloid/majalah \\
\hline 7 & Bila sakit, keluarga saya dapat berobat ke dokter atau Rumah Sakit \\
\hline & Transportasi Rekreasi danTabungan \\
\hline 8 & Saya memiliki uang untuk biaya transportasi sehari-hari \\
\hline 9 & Saya dan keluarga dapat berekreasi paling tidak 2 kali dalam 1 tahun \\
\hline 10 & Dengan bekerja saya dapat menabung \\
\hline & Kesehatan Mental \\
\hline 11 & Kondisi pikiran saya baik dan bersemangat \\
\hline 12 & Saya merasa percaya diri di lingkungan sosial \\
\hline 13 & $\begin{array}{l}\text { Lingkungan tinggal \& sosial saya nyaman (bersih, aman, rapi \& bersifat } \\
\text { kekeluargaan) }\end{array}$ \\
\hline
\end{tabular}

Tabel 3.2: Item komitmen kontinuans (continuance commitment/CC)

\begin{tabular}{|l|l|}
\hline NO & PERNYATAAN CC \\
\hline & Berilah nilai sesuai pikiran anda saat ini \\
\hline 1. & Saya bekerja di sini karena tidak ada pabrik lain yang membayar upah yg lebih besar \\
\hline 2. & Saya akan terus bekerja di sini karena tidak bisa mendapat perusahaan yg lebih baik \\
\hline 3. & Saya bekerja dengan sungguh-sungguh karena takut di PHK \\
\hline 4 & Saya ingin bekerja di pabrik ini untuk waktu yang lama \\
\hline 5 & Saya tidak akan pindah ke pabrik lain \\
\hline 6 & Bekerja di pabrik ini sesuai harapan saya \\
\hline
\end{tabular}


Tabel 3.3 :Item Motivasi (MOT)

\begin{tabular}{|l|l|}
\hline NO & PERNYATAAN MOTIVASI \\
\hline & Berilah nilai untuk tujuan anda bekerja saat ini (sesuai pendapat anda) \\
\hline 1. & Saya bekerja utk menghidupi nafkah keluarga \\
\hline 2. & Saya bekerja di pabrik karena lebih aman dan tidak mudah di PHK \\
\hline 3. & Saya bekerja agar banyak kenalan atau teman \\
\hline 4. & Saya bekerja untuk memperbaiki status sosial \\
\hline 5. & Saya bekerja untuk menunjukkan saya mampu berprestasi \\
\hline
\end{tabular}

Tabel 3.4 : Item praktek dukungan organisasi(PDO)

\begin{tabular}{|l|l|}
\hline NO & PERNYATAAN PDO \\
\hline & Berilah nilai untuk tujuan anda bekerja saat ini (sesuai pendapat anda) \\
\hline 1. & Perusahaan memberi hak-hak bagi karyawan sesuai peraturan pemerintah \\
\hline 2. & Perusahaan memberi dukungan melalui kondisi kerja yang aman dan sehat \\
\hline 3. & Perusahaan memberi dukungan melalui training dan pembekalan dalam pekerjaan \\
\hline
\end{tabular}

\section{Tabel 3.5 : Item dukungan Pemerintah(PD)}

\begin{tabular}{|l|l|}
\hline NO & PERNYATAAN PD \\
\hline & Berilah nilai sesuai keadaan anda \\
\hline 1 & Kemampuan kerja saya meningkat karena mendapat pelatihan \\
\hline 2 & Saya menandatangani perjanjian kerja ketika mulai bekerja \\
\hline 3 & Jika kerja lembur saya selalu mendapat bayaran \\
\hline 4 & Hak cuti saya sesuai dengan peraturan Pemerintah \\
\hline 5 & Upah yang saya terima sesuai dengan UMR/UMP \\
\hline 6 & Upah saya tidak dipotong apabila saya tidak masuk karena sakit \\
\hline 7 & Saya dan keluarga diikutkan dalam program BPJS \\
\hline 8 & Saya menjadi anggota serikat pekerja/serikat buruh. \\
\hline 9 & Karyawan tidak pernah mengalami pemutusan hubungan kerja (PHK) sepihak \\
\hline 10 & Tempat kerja saya tunduk pada peraturan Pemerintah mengenai tenaga kerja \\
\hline
\end{tabular}


Analisis Dukungan Organisasi ... (Sylvia D., Christine W., dan Benedicta E.)

\begin{tabular}{|l|l|}
\hline 11 & $\begin{array}{l}\text { Di tempat saya bekerja pekerja hamil tidak diijinkan untuk bekerja antara pk. 23.00- } \\
07.00\end{array}$ \\
\hline 12 & $\begin{array}{l}\text { Apabila saya bekerja antara pk 23.00-07.00, perusahaan memberikan makanan dan } \\
\text { minuman bergizi. }\end{array}$ \\
\hline 13 & $\begin{array}{l}\text { Apabila saya bekerja antara pk 23.00-05.00, perusahaan menyediakan angkutan antar } \\
\text { jemput. }\end{array}$ \\
\hline 14 & Saya berhak atas cuti melahirkan selama 3 bulan \\
\hline 15 & $\begin{array}{l}\text { Di perusahaan saya jika mengalami keguguran kandungan mendapat cuti istirahat } \\
\text { sesuai keterangan dokter }\end{array}$ \\
\hline 16 & $\begin{array}{l}\text { Di tempat kerja saya disediakan fasilitas yang mendukung pemberian ASI (air } \\
\text { susuibu) }\end{array}$ \\
\hline
\end{tabular}

Tabel 3.6: Item dukungan Serikat Pekerja Indonesia(DSPI)

\begin{tabular}{|l|l|}
\hline NO & PERNYATAAN \\
\hline & Berilah nilai sesuai pendapat anda \\
\hline 1 & SPI peduli pada hak-hak sebagai pekerja untuk saya dan keluarga \\
\hline 2 & SPI memberikan pembelaan hak sebagai pekerja untuk saya dan keluarga \\
\hline 3 & Menjadi anggota SPI bermanfaat dalam menigkatkan kesejahteraan saya dan keluarga \\
\hline 4 & SPI berperan dalam penyelesaian perselisihan di tempat kerja saya \\
\hline 5 & SPI berperan menyalurkan aspirasi dan hak saya sebagai pekerja perempuan \\
\hline
\end{tabular}




\subsection{Analisis Data}

Untuk menganalisis data hasil penelitian peneliti menggunakan Path Analysis untuk mendapatkan gambaran pengaruh dari tiap-tiap variabel dependen terhadap variabel independennya. Preacher dan Hayes menunjukkan bahwa langkah pendekatan kausal digunakan untuk mengidentifikasi apakah variabel memenuhi kriteria mediasi, tiga pendekatan kausal yaitu: (1) adanya pengaruh signifikan antara variabel bebas dengan variabel mediasi terduga, (2) adanya pengaruh signifikan antara variabel mediasi terduga dengan variabel terikat dan (3) adanya pengaruh signifikan antara variabel bebas terhadap variabel terikat melalui variabel mediasi dalam suatu model. Langkah pendekatan kausal mempertahankan bahwa untuk memenuhi hubungan mediasi dalam urutan kausal, analisis untuk efek $c, a$ dan $b$ harus signifikan, dan $c$ ' tidak signifikan. Dalam mediator pada kenyataannya merupakan mekanisme hubungan antara $a$ dan $b$, tanpa adanya variabel mediasi akan melemahkan hubungan menjadi tidak signifikan
(Preacher dan Hayes, 2013). Efek mediasi pengaruh tidak langsung dianalisis melalui bootstrap method. Indirect effect menetapkan sejauh mana variabel independen dan mediator dapat menjelaskan variabel dependen dalam urutan kausal dihitung sebagai $a b=c-c^{\prime}$. Dalam melakukan pengujian ini penulis menggunakan aplikasi SPSS for Windows 22.0 dengan menggunakan macro dan syntax dari Preacher dan Hayes.

\section{ANALISIS DAN PEMBAHASAN}

\subsection{Deskripsi Jawaban Responden}

\section{Uji Validitas dan Realibilitas}

Setelah dilakukan uji validitas dengan uji Cronbachalpha > 0,6 dan realibilitas dengan Corrected Item Total Corelation yang masing-masing harus diatas $\mathrm{r}$ tabel maka beberapa variabel yang tidak valid kemudian didrop sehingga item-item yang digunakna menjadi valid dan realible sebagai berikut. Untuk variabel PDO,CC,MOT, dan DSPI seluruh item memenuhi syarat valid diatas 0.6 dan realible sedangkan untuk QOL syarat validitas belum terpenuhi untuk item Q3, Q4, Q5, Q7 dan Q8 sehingga harus didrop. 
Setelah ke 5 item tersebut di keluarkan Setelah dilakukan uji validitas maka item maka syarat validitas dan realibilitas yang dihunakan selanjutnya adalah item terpenuhi. Begitu pula dalam variabel DP yang telah valid dan reliable.

item Q2, Q5, Q8 dan Q9 juga harus didrop Demografi responden dilihat dari usia, karena tidak memenuhi syarat validitas dan jumlah anak dan lama bekerja adalah realibilitas dan setelah iten tersebut di. sebagai berikut:

\section{Gambar 4.1: Usia, Jumlah anak dan Lama Kerja}
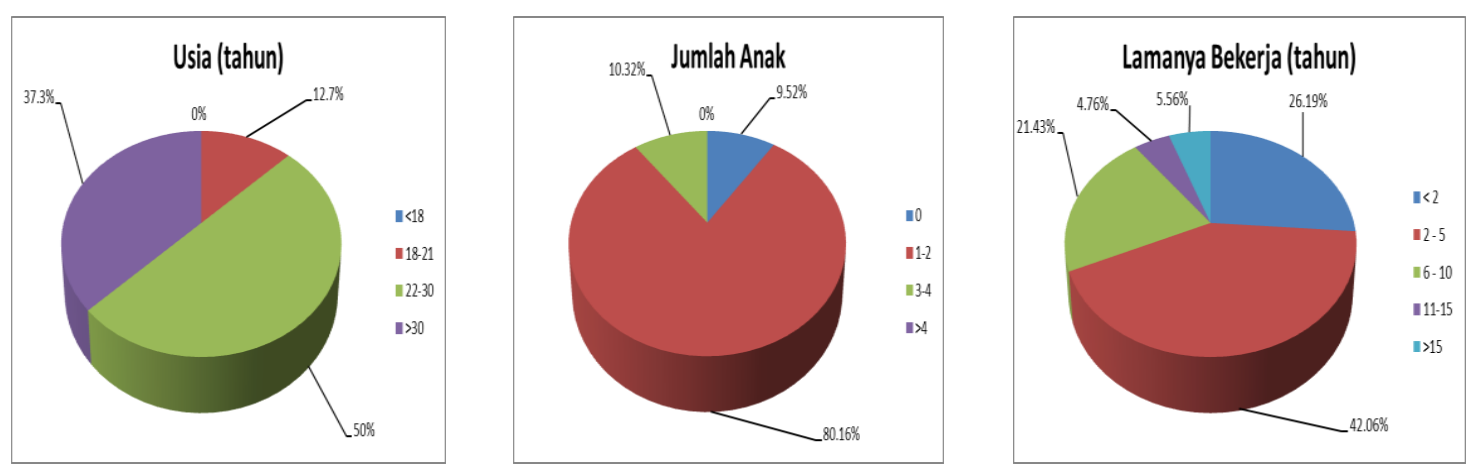

Pada umumnya responden tinggal tidak jauh dari tempat mereka bekerja. Para karyawan menyatakan setuju telah menerima upah sesuai UMR dalam skala 7 dari 10,dimana mereka hanya memiliki tingkat pendidikan SD sampai SMU. Berikut disajikan hasil persepsi partisipan atas item dalam kuesioner dalam overal mean scores untuk item yang telah diuji validitas dan realibilitasnya. 
Tabel 4.1: Rata-rata Untuk Tiap Item

\begin{tabular}{|c|c|c|c|c|c|c|}
\hline NO & $\begin{array}{l}\text { Rata- } \\
\text { rata } \\
\text { MOT }\end{array}$ & $\begin{array}{l}\text { Rata- } \\
\text { rata } \\
\text { QoL }\end{array}$ & $\begin{array}{l}\text { Rata- } \\
\text { rata } \\
\text { PDO }\end{array}$ & $\begin{array}{l}\text { Rata- } \\
\text { rata } \\
\text { CC }\end{array}$ & $\begin{array}{l}\text { Rata- } \\
\text { rata } \\
\text { DP }\end{array}$ & $\begin{array}{l}\text { Rata- } \\
\text { rata } \\
\text { DSPI }\end{array}$ \\
\hline Q1 & 8,8 & 8,1 & 8,6 & 7,9 & 8,7 & 8,5 \\
\hline $\mathbf{Q 2}$ & 7.6 & 9,1 & 9,1 & 6,9 & - & 8,0 \\
\hline Q3 & 8,9 & - & 9,3 & 7,8 & 9,5 & 7,0 \\
\hline Q4 & 8,0 & - & - & 4,7 & 8,7 & 7,7 \\
\hline Q5 & 8,4 & - & - & 6,6 & - & 7,7 \\
\hline Q6 & - & 2,6 & - & 7,3 & 7,6 & - \\
\hline Q7 & - & - & - & - & 8,7 & - \\
\hline Q8 & - & - & - & - & - & - \\
\hline Q9 & - & 4,9 & - & - & - & - \\
\hline Q10 & - & 5,8 & - & - & 8,8 & - \\
\hline Q11 & - & 7,7 & - & - & 7,1 & - \\
\hline Q12 & - & 7,4 & - & - & 6,3 & - \\
\hline Q13 & - & 7,8 & - & - & 4,7 & - \\
\hline Q14 & - & - & - & - & 8,2 & - \\
\hline Q15 & - & - & - & - & 9,2 & - \\
\hline Q16 & - & - & - & - & $\mathbf{4 , 3}$ & - \\
\hline $\begin{array}{l}\text { Rata-rata } \\
\text { keseluruhan }\end{array}$ & 8,34 & 6,7 & 9,0 & 6,9 & 7,7 & 7,8 \\
\hline
\end{tabular}

Sumber: Hasil Olahan Data Penelitian

Berdasarkan hasil perhitungan rata-

rata keseluruhan maka didapat bahwa menurut persepsi responden, motivasi relatif sangat tinggi, pada umumnya mereka setuju bahwa mereka bekerja untuk menghidupi nafkah, mempunyai teman/kenalan, memperbaiki stastus keluarga dan mampu berprestasi dalam score diatas 8 dari 10, sedangkan untuk rasa aman dari PHK juga setuju dengan score
7,6. Untuk kualitas hidup atau quality of life (QoL) jawaban sangat bervariasi.Mereka setuju dengan bekerja dapat memenuhi makan sehat dan tinggal di rumah yang layak dan dapat memenuhi kebutuhan hidup sehari-hari pada score diatas 8, Meskipun pada pretest pernyataan untuk anak-anak dapat bersekolah pada usia sekolah dan dapat berobat bila sakit scorenya tinggi namun pernyataan ini harus didrop karena 
tidak valid. Sedangkan jawaban untuk menabung relatif rendah pada score 4,9 namun untuk lingkungan dan kesehatan mental baik di score di atas 7. Secara keseluruhan kualitas hidup berada pada score 6,7. Praktek dukungan organisasi (PDO) relatif tinggi dimana kondisi kerja yang aman dan sehat serta dukungan untuk pelatihan dan pembekalan berada di score diatas 9 , dan dukungan hak sesuai peraturan mendapat score 8,6. Commitment continuance (CC) juga relatif tinggi berada pada score di atas 6 kecuali keinginan bekerja untuk jangka waktu yang lama berada di score relatif rendah 4,7.
Dukungan pemerintah juga relatif tinggi kecuali untuk aturan transport pulang malam dan fasilitas pemberian asi berada pada score rendah di bawah 5, Sementara itu dukungan serikat pekerja Indonesia (DSPI) juga relatif tinggi semua indikator berada pada score di atas 7. Dari hasil deskripsi ini didapat gambaran bahwa score terendah dipersepsikan untuk kualitas hidup tetapi sangat di luar dugaan score untuk dukungan organisasi ternyata menjadi score tertinggi.

\begin{tabular}{|l|l|l|l|l|l|l|}
\hline \multicolumn{6}{|l|}{ Model Summary } \\
\hline R & R-sq & MSE & F & df1 & df2 & $p$ \\
\hline, 6722 &, 4518 & 3,0147 & 19,7832 & 5,0000 & 120,0000 &, 0000 \\
\hline
\end{tabular}

Tabel 4.1: Hasil analisis jalur Model Summary Sumber: Hasil Olahan untuk Penelitian

\subsection{Analisis jalur model 1}

Hasil analisis jalur untuk Model 1

dengan menggunakan software macros dari

Hayes, 2013 adalah sebagai berikut:

$\operatorname{Model}($ Template $)=10 ; \mathrm{Y}=\mathrm{QoL} ; \mathrm{X}=\mathrm{MOT}$;

$\mathrm{M}=\mathrm{CC} ; \mathrm{W}=\mathrm{PDO} ; \mathrm{Z}=\mathrm{DSPI}$; Sample size =

126. 
Outcome: $\mathrm{CC}$

Interactions:

int 1 MOT $\mathrm{X}$ PDO

int 2 MOT $X \quad$ DSPI

Tabel 4. 2: Hasil analisis Jalur Struktur 1

\begin{tabular}{|l|l|l|l|l|l|l|}
\hline Model & coeff & se & $\mathrm{t}$ & $\mathrm{p}$ & LLCI & ULCI \\
\hline constant & 2,6242 & 1,7730 & 1,4801 &, 1415 &,- 8861 & 6,1345 \\
\hline MOT &, 3209 &, 2888 & 1,1111 &, 2687 &,- 2509 &, 8927 \\
\hline PD0 &, 7788 &, 2347 & 3,3189 &, 0012 &, 3142 & 1,2434 \\
\hline int_1 &,- 0878 &, 0351 & $-2,5043$ &, 0136 &,- 1572 &,- 0184 \\
\hline DSPI & $-1,0603$ &, 2749 & $-3,8570$ &, 0002 & $-1,6045$ &,- 5160 \\
\hline int_2 &, 1438 &, 0324 & 4,4370 &, 0000 &, 0796 &, 2079 \\
\hline
\end{tabular}

Sumber: Hasil Olahan untuk Penelitian

Dari hasil uji diketahui bahwa organisasi seperti pemenuhan hak-hak secara total seluruh variabel (MOT,PDO karyawan sesuai peraturan pemerintah, dan DSPI) dapat berpengaruh signifikan kondisi kerja yang aman dan sehat juga terhadap komitmen kontinuans (CC) pemberian pembekalan dan training namun bila dilihat secara parsial berpengaruh signifikan meningkatkan motivasi(MOT) tidak berpengaruh komitmen buruh perempuan. Namun signifikan baik terhadap QoLmaupun CC dukungan serikat pekerja justru sehingga hipotesis 1 dan hipotesis 2 dalam menurunkan komitmen buruh perempuan, model 1 tidak dapat diterima. Di sisi lain hasil ini tidak relevan dengan temuan praktek dukungan organisasi(PDO) Pencavel, 2009 dimana serikat pekerja signifikan berpengaruh terhadap $\mathrm{CC}$ hasil dinyatakan dapat mendukung peningkatan mendukung temuan Eisenberger, et al., kesejahteraan karyawan yang tentunya 1986 dalam Taing, et., al, 2011. dapat meningkatkan komitmen (Bishop and Sementara,dukungan serikat pekerja (DSPI) Scott, 2000; Liden, et al., 2003). Hal ini signifikan dalam arah terbalik. Dari hasil ini mungkin saja karena responden diketahui bahwa praktek dukungan mempersepsikan dukungan serikat pekerja 
Analisis Dukungan Organisasi ... (Sylvia D., Christine W., dan Benedicta E.)

justru memberi kesadaran bagi buruh dukungan organisasi menjadi faktor yang perempuan akan peluang-peluang yang meningkatkan komitmen.

lebih baik yang mungkin diperoleh bila

Dari hasil ini dapat digambarkan meninggalkan organisasi, sehingga dari hasil ditunjukkan pengaruh dalam arah terbalik.

Dari hasil ditemukan pula bahwa variabel moderasi PDO dan DSPI ketika dimasukkan dalam model sebagai moderasi secara parsial signifikan, namun hasil ini memiliki arah koefisien yang tidak sama dimana koefisien moderasi MOTxPDO adalah negatif sedangkan koefisien MOTxDSPI positif. Tetapi bila dilihat secara simultan moderasi tersebut tidak signifikan dalam setiap kondisi sesuai kriteria yang dinyatakan Hayes, 2013 (lihat tabel 1 dan 2 dalam lampiran). Hal ini berarti bahwa moderasi MOTxPDO pada pengaruh MOT terhadap CC dan moderasi MOTxDSPI pada pengaruh MOT terhadap CC secara simultan tidak signifikan, dengan demikian hipotesis 4 dan hipotesis 5 dalam model 1 juga tidak dapat diterima. Hasil ini berbeda dengan temuan Bishop and Scott, 2000; Liden, et al., 2003 yang menyatakan

bahwa secara parsial dukungan serikat pekerja dapat menjadi pertimbangan dalam motivasi buruh perempuan dalam bekerja untuk meningkatkan komitmen kontinuans dimana kehadiran serikat pekerja bagi mereka menjadi penting dalam pertimbangan untuk tetap bertahan atau tidak di organisasi dengan informasi yang diberikansebagai pihak yang membela kepentingan mereka.Hasil berbeda ketika dilakukan interaksi MOTxPDO sebaliknya secara parsial hasil moderasi praktek dukungan organisasi justru memperlemah pengaruh motivasi perempuan terhadap komitmen kontinuan yang dipersepsikan. Justifikasi dari hal ini dapat dikaitkan dengan hasil deskripsi jawaban partisipan, diperkirakan meskipun PDO yang dipersepsikan sudah baik namun hal tersebut mempunyai arah yang berbeda bila diintegrasikan dengan motivasi buruh perempuan, dimana motivasi dan dukungan yang relatif tinggi dipersepsikan justru tidak searah dengan komitmen, hal ini relevan 
dengan temuan Purba, 2013 yang sehingga kehadiran serikat pekerja tidak menyatakan dukungan organisasi tidak mendorong partisipan untuk berkomitmen signifikan pada level 5\% dalam dalam hal ini komitmen kontinuans. meningkatkan keinginan untuk bertahan pada karyawan wanita yang bekerja di Bank-bank di Jakarta, namun berbeda dengan temuan Trevino, et., al (1998) dalam Erben dan Guneser (2008) yang menyatakan dukungan organisasi berpengaruh terhadap komitmen untuk tinggal.

Persepsi buruh atas motivasi yang tinggi tidak diikuti persepsi yang sama terhadap dukungan organisasi atau sebaliknya. Hasil ini juga menunjukkan tiap buruh merasakan dampak dukungan yang berbeda meskipun motivasi mereka relatif tinggi.Dengan demikian meskipun buruh perempuan menyatakan bahwa mereka mempersepsikan dukungan organisasi relatif baik namun ada faktor lain yang membuat mereka berkomitmen dimana hal itu bukan dari dukungan organisasi.Hasil ini juga menunjukkan bahwa persepsi buruh perempuan terhadap motivasi yang tinggi tidak diikuti arah yang sama dengan persepsi terhadap dukungan serikat pekerja, 
Analisis Dukungan Organisasi ... (Sylvia D., Christine W., dan Benedicta E.)

Outcome: QoL

Interactions:

int_3 MOT $\mathrm{X}$ PDO

int_4 MOT $\mathrm{X}$ DSPI

Tabel 4.3: Hasil analisis Jalur Struktur 2

\begin{tabular}{|l|l|l|l|l|l|l|}
\hline \multicolumn{6}{|l|}{ Model Summary } \\
\hline R & R-sq & MSE & F & df1 & df2 & $p$ \\
\hline, 1823 &, 0332 & 2,1925 &, 6817 & 6,0000 & 119,0000 &, 6647 \\
\hline
\end{tabular}

Sumber: Hasil Olahan untuk Penelitian

Tabel 4.4: Hasil analisis Jalur Struktur 2

\begin{tabular}{|l|l|l|l|l|l|l|}
\hline Model & coeff & se & t & $p$ & LLCI & ULCI \\
\hline constant & 4,0696 & 1,5257 & 2,6674 &, 0087 & 1,0486 & 7,0907 \\
\hline CC &, 0072 &, 0778 &, 0927 &, 9263 &,- 1469 &, 1614 \\
\hline MOT &, 4617 &, 2476 & 1,8650 &, 0646 &,- 0285 &, 9519 \\
\hline PD0 &, 1920 &, 2091 &, 9184 &, 3603 &,- 2220 &, 6061 \\
\hline int_3 &,- 0404 &, 0307 & $-1,3181$ &, 1900 &,- 1011 &, 0203 \\
\hline DSPI &, 0783 &, 2485 &, 3152 &, 7532 &,- 4138 &, 5705 \\
\hline int_4 &,- 0066 &, 0298 &,- 2224 &, 8244 &,- 0657 &, 0524 \\
\hline
\end{tabular}

Sumber: Hasil Olahan untuk Penelitian

Hasil analisis secara parsial ternyata berbeda dengan hasil uji secara simultan dengan memasukkan variabel QOL sebagai variabel outcome, dimana PDO dan DSPI menjadi moderasi pada pengaruh motivasi terhadap kualitas hidup yang dimediasi komitmen kontinuans.Hasil yang didapat secara total baik MOT,PDO,DSPI dan CC tidak signifikan berpengaruh terhadap QOL.Dari hasil uji juga ditemukan sebagai variabel moderasi baik PDO maupun DSPI tidak memiliki efek moderasi yang signifikan dalam pengaruh motivasi terhadap komitmen maupun motivasi terhadap kualitas hidup.

Dari hasil penelitian ini diketahui bahwa bila dukungan organisasi dan dukungan serikat pekerja dimasukkan sebagai variabel yang dapat berpengaruh sebagai pihak internal dimana serikat 
pekerja adalah wakil buruh didalam organisasi, ternyata motivasi tidak dapat meningkatkan komitmen maupun kualitas hidup buruh perempuan di Jabodetabek., hasil ini berbeda dengan pendapat Clarke and Islam, 2004 dalam Lazim \& Osman 2009; Zeytinoglu et al., 2007; Taing et al., 2011 yang menyatakan dukungan organisasi berhubungan dengan tingkat kesejahteraan karyawan.Dari hasil tersebut dalam kasus penelitian ini bila dilihat dalam model 1 dimana persepsi buruh atas kualitas hidupnya secara simultan tidak dipengaruhi motivasi, praktek dukungan organisasi, dukungan serikat pekerja maupun komitmen kontinuans. Hal ini juga terlihat untuk hasil uji pada moderasi DP maupun DSPI dalam berbagai kondisi hasil pengolahan data dengan menggunakan macros Hayes 2013 (lihat lampiran tabel1). 
Analisis Dukungan Organisasi ... (Sylvia D., Christine W., dan Benedicta E.)

\subsection{Analisis jalur model 2}

Hasil analisis jalur untuk Model 2 dapat dilihat sebagai berikut.

Model $($ Template $)=17 ; \mathrm{Y}=\mathrm{QoL} ; \mathrm{X}=\mathrm{MOT} ; \mathrm{M}=\mathrm{CC} ; \mathrm{V}=\mathrm{DP} ; \mathrm{Q}=\mathrm{DSPI}$

Outcome : CC

Tabel 4.5: Hasil analisis Jalur Model Sumary

\begin{tabular}{|l|l|l|l|l|l|l|}
\hline \multicolumn{6}{|l|}{ Model Summary } \\
\hline R & R-sq & MSE & F & df1 & df2 & p \\
\hline, 5705 &, 3255 & 3,5901 & 59,8301 & 1,0000 & 124,0000 &, 0000 \\
\hline
\end{tabular}

Sumber: Hasil Olahan untuk Penelitian

Tabel 4.6: Hasil analisis Jalur Struktur 1

\begin{tabular}{|l|l|l|l|l|l|l|}
\hline Model & coeff & se & $\mathrm{t}$ & $\mathrm{p}$ & LLCI & ULCI \\
\hline constant & 1,8011 &, 6910 & 2,6065 &, 0103 &, 4334 & 3,1688 \\
\hline MOT &, 6214 &, 0803 & 7,7350 &, 0000 &, 4624 &, 7804 \\
\hline
\end{tabular}

Sumber: Hasil Olahan untuk Penelitian

Outcome: QoL

Interactions:

int_1 CC $\mathrm{X} \quad \mathrm{DP}$

int_2 $\mathrm{CC} \quad \mathrm{X} \quad \mathrm{DSPI}$

int_3 MOT $X \quad \mathrm{DP}$

int_4 MOT $\mathrm{X}$ DSPI

Tabel 4.7: Hasil Analisis Jalur Model Sumary

\begin{tabular}{|l|l|l|l|l|l|l|}
\hline \multicolumn{9}{|l|}{ Model Summary } \\
\hline R & R-sq & MSE & F & df1 & df2 & $p$ \\
\hline, 3607 &, 1301 & 2,0064 & 2,1880 & 8,0000 & 117,0000 &, 0331 \\
\hline
\end{tabular}

Sumber: Hasil Olahan untuk Penelitian 
Tabel 4.8: Hasil Analisis Jalur Struktur 2

\begin{tabular}{|l|l|l|l|l|l|l|}
\hline Model & coeff & se & $\mathrm{t}$ & $\mathrm{p}$ & LLCI & ULCI \\
\hline constant & $-2,3190$ & 2,4384 &,- 9510 &, 3435 & $-7,1481$ & 2,5101 \\
\hline CC &, 8046 &, 3387 & 2,3757 &, 0191 &, 1339 & 1,4753 \\
\hline MOT &, 4366 &, 3256 & 1,3410 &, 1825 &,- 2082 & 1,0814 \\
\hline DP & 1,7791 &, 5274 & 3,3735 &, 0010 &, 7346 & 2,8235 \\
\hline DSPI &,- 4965 &, 2848 & $-1,7431$ &, 0839 & $-1,0605$ &, 0676 \\
\hline int_1 &,- 1532 &, 0612 & $-2,5025$ &, 0137 &,- 2744 &,- 0320 \\
\hline int_2 &, 0432 &, 0323 & 1,3362 &, 1841 &,- 0208 &, 1072 \\
\hline int_3 &,- 0896 &, 0649 & $-1,3812$ &, 1699 &,- 2181 &, 0389 \\
\hline int_4 &, 0306 &, 0352 &, 8681 &, 3871 &,- 0392 &, 1003 \\
\hline
\end{tabular}

Sumber: Hasil Olahan untuk Penelitian

Model 2 ini menguji bagaimana Motivasi berpengaruh terhadap kualitas hidup yang dimediasi komitmen dimana dukungan serikat pekerja dan dukungan pemerintah sebagai pihak eksternal dapat memperkuat baik pengaruh motivasi maupun komitmen terhadap kualitas hidup. Dari hasil uji parsial pada model 2 diketahui MOT berpengaruh positif signifikan terhadap CC bila CC sebagai outcome. Pengaruh tersebut cukup kuat bila dilihat dari besar koefisien 0,6214 dengan tingkat signifikansi 0,000. Hasil ini menunjukkan bila dilihat dalam hasil uji dengan memasukkan unsur dukungan pemerintah dan serikat pekerja maka motivasi dapat meningkatkan komitmen pada buruh perempuan. Namun lebih jauh pada struktur jalur dimana QOL menjadi outcome maka MOT tidak memiliki pengaruh signifikan terhadap QOL atau motivasi tidak dapat meningkatkan kualitas hidup para buruh perempuan. Sebaliknya komitmen kontinuans (CC) berpengaruh positif dalam meningkatkan kualitas hidup (QOL), namun dari hasil uji model ini ditemukan bahwa komitmen kontinuans tidak signifikan memediasi pengaruh motivasi terhadap kualitas hidup. Dengan kata lain, motivasi tidak berpengaruh langsung terhadap kualitas hidup dan tidak dapat berpengaruh melalui komitmen kontinuans yang dimiliki buruh perempuan tersebut. 
Hasil lain yang ditemukan adalah dukungan Pemerintah memiliki pengaruh yang signifikan terhadap kualitas hidup dengan koefisien yang tinggi yaitu 1,7791 dengan tingkat signifikansi 0,0010. Hasil yang tidak lazim tampak pada dukungan Pemerintah yang memoderasi komitmen kontinuan terhadap kualitas hidup justru memberi moderasi dalam arah terbalik.Hasil ini agak membingungkan karena semestinya dengan komitmen kontinuan yang dipersepsikan buruh perempuan akan semakin berpengaruh terhadap peningkatan kualitas hidup mereka bila ada dukungan Pemerintah. Temuan ini juga tidak mendukung pendapat Kaufman, 2000 dan Adler 2006 yang menyatakan dukungan Pemerintah sangat berarti dalam memberi perlindungan maupun meningkatkan kesejahteraan para pekerja. Penjelasan yang dapat diduga dari hasil ini adalah komitmen kontinuan yang dipersepsikan partisipan tidak searah dengan persepsi terhadap dukungan Pemerintah. Artinya partisipan yang mempersepsikan tinggi untuk komitmen ternyata mempersepsikan dukungan
Pemerintah tidak selalu dalam arah yang sama bisa saja mempersepsikan dukungan Pemerintah lebih rendah. Sementara untuk variabel interaksi lain yaitu CCxDSPI, MOTxDP dan MOTxDSPI ditemukan tidak signifikan memoderasi pengaruh komitmen dan motivasi terhadap kualitas hidup. Hasil ini berbeda dengan hasil riset yang diacu oleh Milkovich 2014 sepertiriset Jarrel \& Stanley 1990 yang menyatakan perbedaan kehadiran serikat pekerja terhadap kehidupan karyawan dalam kondisi ekonomi yang kurang baik atau pengangguran tinggi signifikan, namun akan kurang bermakna ketika kondisi ekonomi kuat.Jadi model ini menggambarkan bahwa baik dukungan Pemerintah, dukungan serikat pekerja bila diuji secara simultan dalam model moderasi pada pengaruh motivasi terhadap kualitas hidup tidak mempunyai efek moderasi, dan komitmen tidak dapat memediasi dalam berbagai kondisi pengujian (seperti yang terlihat pada tabel conditional di lampiran). Model 3 disajikan untuk menguji komitmen kontinuans buruh perempuan dalam model terpisah dapat mempengaruhi 
kualitas hidup yang dimoderasi dukungan

Pemerintah maupun dukungan serikat

Pekerja. Model ini juga dibangun untuk melihat bagaimana buruh perempuan bertahan dalam pekerjaannya dalam meningkatkan kualitas hidup dimana Pemerintah dan Serikat Pekerja ikut memberi dukungan. Berikut hasil uji terhadap model tersebut.

\subsection{Analisis jalur model 3}

Hasil analisis jalur untuk Model 3 dapat dilihat sebagai berikut.

Model $($ Template $)=2 ; \mathrm{Y}=\mathrm{QoL} ; \mathrm{X}=\mathrm{CC} ; \mathrm{M}=\mathrm{DP} ; \mathrm{W}=\mathrm{DSP} ;$ Sample size 126

Outcome: QoL

Interactions:

$\begin{array}{llll}\text { int_1 } & \text { CC } & \text { X } & \text { DP } \\ \text { int_2 } & \text { CC } & \text { X } & \text { DSPI }\end{array}$

Tabel 4.9: Hasil Analisis Jalur Model Sumary

\begin{tabular}{|l|l|l|l|l|l|l|}
\hline \multicolumn{5}{|l|}{ Model Summary } \\
\hline R & R-sq & MSE & F & df1 & df2 & p \\
\hline, 3277 &, 1074 & 2,0074 & 2,8872 & 5,0000 & 120,0000 &, 0169 \\
\hline
\end{tabular}

Sumber: Hasil Olahan untuk Penelitian

Tabel 4.10: Hasil Analisis Jalur Struktur 2

\begin{tabular}{|l|l|l|l|l|l|l|}
\hline Model & coeff & se & $\mathrm{t}$ & $\mathrm{p}$ & LLCI & ULCI \\
\hline constant &, 1339 & 1,7991 &, 0744 &, 9408 & $-3,4281$ & 3,6960 \\
\hline DP & 1,2065 &, 3539 & 3,4090 &, 0009 &, 5058 & 1,9072 \\
\hline CC & 1,0043 &, 2796 & 3,5923 &, 0005 &, 4508 & 1,5579 \\
\hline int_1 &,- 1848 &, 0535 & $-3,4552$ &, 0008 &,- 2907 &,- 0789 \\
\hline DSPI &,- 2646 &, 1952 & $-1,3556$ &, 1778 &,- 6510 &, 1219 \\
\hline int_2 &, 0488 &, 0298 & 1,6398 &, 1037 &,- 0101 &, 1078 \\
\hline
\end{tabular}

Sumber: Hasil Olahan untuk Penelitian 


\section{Analisis Dukungan Organisasi ... (Sylvia D., Christine W., dan Benedicta E.)}

Tabel 4.11: R-square increase due to interaction(s)

\begin{tabular}{|l|l|l|l|l|l|}
\hline \multicolumn{1}{|l|}{ Model Summary } \\
\hline & R-chng & F & df1 & df2 & $p$ \\
\hline int_1 &, 0888 & 11,9384 & 1,0000 & 120,0000 &, 0008 \\
\hline int_2 &, 0200 & 2,6890 & 1,0000 & 120,0000 &, 1037 \\
\hline Both &, 1023 & 6,8764 & 2,0000 & 120,0000 &, 0015 \\
\hline
\end{tabular}

Sumber: Hasil Olahan untuk Penelitian

Tabel 4.12: Conditional effect of $\mathrm{X}$ on $\mathrm{Y}$ at values of the moderator(s)

\begin{tabular}{|c|c|c|c|c|c|c|c|}
\hline DSPI & $\mathrm{DP}$ & Effect & se & $t$ & $\mathrm{p}$ & LLCI & ULCI \\
\hline 4,0000 & 5,0000 &, 2755 &, 1058 & 2,6037 &, 0104 &, 0660 &, 4849 \\
\hline 4,0000 & 6,0000 &, 0906 &, 0928 &, 9770 &, 3306 &,- 0930 &, 2743 \\
\hline 4,0000 & 8,0000 &,- 2790 &, 1435 & $-1,9440$ &, 0542 &,- 5632 &, 0052 \\
\hline 4,0000 & 9,0000 &,- 4639 &, 1876 & $-2,4729$ &, 0148 &,- 8353 &,- 0925 \\
\hline 4,0000 & 10,0000 &,- 6487 &, 2356 & $-2,7538$ &, 0068 & $-1,1151$ &,- 1823 \\
\hline 5,0000 & 5,0000 &, 3243 &, 1088 & 2,9817 &, 0035 &, 1090 &, 5396 \\
\hline 5,0000 & 6,0000 &, 1395 &, 0830 & 1,6799 &, 0956 &,- 0249 &, 3038 \\
\hline 5,0000 & 8,0000 &,- 2302 &, 1191 & $-1,9327$ &, 0556 &,- 4660 &, 0056 \\
\hline 5,0000 & 9,0000 &,- 4150 &, 1625 & $-2,5534$ &, 0119 &,- 7369 &,- 0932 \\
\hline 5,0000 & 10,0000 &,- 5999 &, 2107 & $-2,8476$ &, 0052 & $-1,0170$ &,- 1828 \\
\hline 8,0000 & 5,0000 &, 4708 &, 1561 & 3,0155 &, 0031 &, 1617 &, 7799 \\
\hline 8,0000 & 6,0000 &, 2859 &, 1113 & 2,5694 &, 0114 &, 0656 &, 5063 \\
\hline 8,0000 & 8,0000 &,- 0837 &, 0747 & $-1,1209$ &, 2646 &,- 2316 &, 0642 \\
\hline 8,0000 & 9,0000 &,- 2686 &, 1037 & $-2,5889$ &, 0108 &,- 4739 &,- 0632 \\
\hline 8,0000 & 10,0000 &,- 4534 &, 1472 & $-3,0802$ &, 0026 &,- 7448 &,- 1620 \\
\hline 10,0000 & 5,0000 &, 5684 &, 2040 & 2,7869 &, 0062 &, 1646 &, 9723 \\
\hline 10,0000 & 6,0000 &, 3836 &, 1578 & 2,4303 &, 0166 &, 0711 &, 6961 \\
\hline 10,0000 & 8,0000 &, 0139 &, 0933 &, 1493 &, 8816 &,- 1708 &, 1987 \\
\hline 10,0000 & 9,0000 &,- 1709 &, 0959 & $-1,7830$ &, 0771 &,- 3607 &, 0189 \\
\hline 10,0000 & 10,0000 &,- 3557 &, 1241 & $-2,8673$ &, 0049 &,- 6014 &,- 1101 \\
\hline 10,0000 & 5,0000 &, 5684 &, 2040 & 2,7869 &, 0062 &, 1646 &, 9723 \\
\hline 10,0000 & 6,0000 &, 3836 &, 1578 & 2,4303 &, 0166 &, 0711 &, 6961 \\
\hline 10,0000 & 8,0000 &, 0139 &, 0933 &, 1493 &, 8816 &,- 1708 &, 1987 \\
\hline 10,0000 & 9,0000 &,- 1709 &, 0959 & $-1,7830$ &, 0771 &,- 3607 &, 0189 \\
\hline 10,0000 & 10,0000 &,- 3557 &, 1241 & $-2,8673$ &, 0049 &,- 6014 &,- 1101 \\
\hline
\end{tabular}

Sumber: Hasil Olahan untuk Penelitian 
Dalam model 3 pengujian dilakukan terlepas dari efek motivasi dalam faktor yang mempengaruhi kualitas hidup buruh.Dari model 3, diketahui bahwa komitmen kontinuans berpengaruh signifikan terhadap kualitas hidup buruh perempuan dengan koefisien kuat 1,0043 dalam arah positif. Demikian pula pengaruh dukungan Pemerintah terhadap kualitas hidup buruh perempuan berpengaruh signifikan dengan koefisien kuat 1,2065 sedangkan dukungan serikat pekerja ternyata tidak berpengaruh signifikan dalam model 3 ini. Lebih lanjut diketahui dukungan pemerintah dapat memoderasi pengaruh komitmen terhadap kualitas hidup. Hasil ini menunjukkan bahwa para buruh perempuan mempersepsikan komitmen mereka dapat meningkatkan kualitas hidup. Sementara itu persepsi mereka terhadap komitmen juga searah dengan persepsi mereka terhadap dukungan pemerintah. Pemerintah turut memberi dukungan dalam upaya tersebut melalui peraturan yang disusun dalam perundangundangan berkaitan dengan ketenagakerjaan. Sementara dukungan serikat pekerja ternyata tidak berpengaruh dan tidak dapat memoderasi pengaruh komitmen terhadap kualitas hidup. Namun dalam interaksi dukungan pemerintah dan serikat pekerja secara bersama-sama dapat memperkuat pengaruh komitmen terhadap kualitas hidup Hal ini menunjukkan bahwa menurut persepsi buruh perempuan dukungan serikat pekerja harus bersama dengan dukungan pemerintah agar dapat memberi kontribusi terhadap kualitas hidup yang dirasakan saat ini.

Dari temuan dalam model 3 diketahui bahwa ketika motivasi buruh dimasukkan dalam model 1 dan 2 maka motivasi sebagai variabel independen tidak mempengaruhi kualitas hidup buruh. Persepsi buruh atas motivasi tidak berasosiasi dengan kualitas hidup, dan dukungan serikat pekerja.Namun, dalam model 3 komitmen kontinuans berpengaruh signifikan terhadap motivasi dan secara bersama-sama dukungan Pemerintah dan serikat pekerja juga signifikan memoderasi komitmen terhadap kualitas hidup. Hasil dalam model 3 ini menjadi relevan dengan riset Jarrel \& Stanley, 1990; Kaufman 2000 
Analisis Dukungan Organisasi ... (Sylvia D., Christine W., dan Benedicta E.)

dalam Milkovich, 2014 dan Adler 2006 dalam Lim 2010.

\subsection{Diskusi}

Dari hasil penelitian yang diuji dalam 3 model yang telah dipaparkan maka ada beberapa hal yang menjadi temuan penelitian ini. Dari model pertama secara simultandiketahui dukungan organisasi dan dukungan serikat pekerja tidak dapat memoderasi motivasi terhadap komitmen buruh perempuan. Sementara komitmen kontinuans tidak dapat memediasi pengaruh motivasi terhadap kualitas hidup ketika dukungan organisasi dan dukungan serikat pekerja dimasukkan sebagai variabel moderasinya. Artinya dilihat dari persepsi buruh perempuan dukungan dari dalam organisasi baik dukungan organisasi dan serikat pekerja tidak dapat memoderasi motivasi terhadap komitmen, namun secara parsial dukungan organisasi dapat meningkatkan komitmen sedangkan dukungan serikat pekerja menurunkan komitmen. Hasil menunjukkan bahwa dukungan organisasi yang dipersepsikan tidak sesuai dengan kenyataan dalam pengaruhnya terhadap kualitas hidup. Hal ini berbeda dengan temuan yang terjadi di negara majuseperti dalam riset Trevino, et., al (1998) dalam Erben dan Guneser (2008); Bishop and Scott, 2000; Liden, et., al. 2003, namun relevan dengan temuan Purba, 2013 yang dilakukan di Indonesia. Dari hasil ini dapat dikemukakan bahwa dukungan organisasi pada beberapa kasus di Indonesia belum dipersepsikan sebagai faktor yang dapat meningkatkan komitmen maupun kualitas hidup karyawan. Begitu pula tidak sesuai dengan riset Jarrel \& Stanley 1990 dalam Milcovich 2014 yang menyatakan kehadiran serikat pekerja signifikan bermakna dalam kondisi ketika tingkat pengangguran tinggi. Temuan ini menunjukkan bahwa motivasi buruh untuk bekerja tidak dapat meningkatkan kualitas hidup buruh meskipun dukungan organisasi dan serikat pekerja dipersepsikan relatif baik.Dari hasil ini, gambaran kualitas hidup buruh perempuan di Jabotabek tampaknya perlu ditingkatkan, terutama pada kebutuhan rekreasi dan kemampuan menabung yang masih rendah. Meski dukungan organisasi dipersepsikan tinggi namun hasil ini tidak dapat mendorong 


\section{Journal of Management Vol.13, No.1, January 2016: 41-87 and Business Review}

motivasi buruh untuk bertahan dalam upaya meningkatkan kualitas hidup.

Hasil lain ditemukan dalam model kedua, secara parsial motivasi berpengaruh terhadap komitmen ketika dukungan eksternal yakni dukungan Pemerintah dan serikat pekerja dimasukkan sebagai moderasi pada pengaruh motivasi dan komitmen terhadap kualitas hidup. Dari hasil ini juga ditemukan bahwa komitmen, dukungan organisasi dan dukungan serikat pekerja berpengaruh signifikan terhadap kualitas hidup namun motivasi tidak signifikan berpengaruh terhadap kualitas hidup. Namun bila dilihat secara simultan dukungan Pemerintah dan serikat pekerja tidak dapat memoderasi pengaruh motivasi terhadap komitmen maupun pengaruh motivasi terhadap kualitas hidup dan begitu pula komitmen tidak dapat memediasi pengaruh motivasi terhadap kualitas hidup. Temuan ini juga tidak sesuai dengan beberapa temuan riset yang menyatakan bahwa baik Pemerintah maupun serikat pekerja berperan dalam meningkatkan kualitas hidup pekerja. Motivasi buruh dalam bekerja ternyata tidak berasosiasi dengan kualitas hidup yang dipersepsikan bersama dukungan Pemerintah maupun serikat pekerja. Tampaknya motivasi tidak mampu menjelaskan baik komitmen maupun kualitas hidup buruh, meskipun dukungan serikat pekerja dan Pemerintah dianggap relatif baik. Hail ini tidak sesuai dengan riset-riset Bishop and Scott, 2000; Liden, et., al. 2003; Pencavel, 2009.

Akhirnya model 3 menggambarkan bila dilihat secara terpisah komitmen kontinuans para buruh perempuan untuk tetap bertahan di pabrik ternyata berpengaruh signifikan terhadap kualitas hidup yang dirasakan. Hasil ini juga menunjukkan bahwa dukungan Pemerintah melalui peraturan ketenagakerjaan dipersepsikan turut beperan dalam pengaruh komitmen terhadap kualitas hidup tersebut. Namun tidak demikian dengan dukungan serikat pekerja yang dianggap bukan variabel yang memperkuat komitmen dalam meningkatkan kualitas hidup mereka. Dengan demikian kualitas hidup lebih dapat dijelaskan oleh komitmen buruh yang dimoderasi secara bersama-sama oleh dukungan Pemerintah dan serikat pekerja. 
Temuan ini menunjukkan bahwa buruh mempersepsikan bahwa dengan berkomitmen maka kualitas hidup mereka dapat ditingkatkan dimana dukungan serikat pekerja serta Pemerintah bermakna dalam meningkatkan kualitas hidup tersebut. Artinya, motivasi justru tidak bermakna meningkatkan kualitas hidup baik langsung maupun melalui komitmen kontinuans sedangkan dengan berkomitmen, buruh menganggap kualitas hidupnya dapat ditingkatkan. Hasil ini menunjukkan bahwa buruh perempuan membutuhkan peran serikat pekerja bersama Pemerintah untuk terus memberi dukungan dalam komitmen kontinuans yang telah diupayakan untuk peningkatan kualitas hidup mereka.

\subsection{Keterbatasan Penelitian}

Dalam penelitian ini disadari beberapa keterbatasan yang membuat riset ini tidak dapat digeneralisir untuk semua buruh perempuan yang berada di Jabodetabek. Beberapa keterbatasan antara lain yakni:
- Sulitnya untuk menghitung populasi buruh perempuan yang menikah dan memiliki anak di Jabodetabek sehingga sampel dilakukan hanya bersifat convinience sampling.

- Sulitnya mendapat data yang lengkap dan terpercaya sehingga sampel penelitian yang digunakan terbatas.

- Karakteritik responden dengan tingkat pendidikan rendah menjadi salah satu konstrain dalam mendisain indikator yang lebih lengkap karena kesulitan untuk mengisi dan memahami kuesioner dengan indikator yang lebih detil.

\section{KESIMPULAN}

Buruh perempuan yang menjadi responden dalam penelitian ini mempersepsikan bahwa mereka memiliki motivasi, komitmen kontinuans yang relatif tinggi dan kualitas hidup juga relatif baik. Di sisi lain partisipan juga mempersepsikan dukungan organisasi, dukungan serikat pekerja dan dukungan pemerintah juga relatif baik. Namun demikian, secara 
simultan dukungan organisasi maupun serikat pekerja tidak dapat memoderasi pengaruh motivasi terhadap kualitas hidup dalam model pengaruh motivasi terhadap kualitas hidup yang dimediasi komitmen. Hasil lain juga menunjukkan bahwa secara parsial komitmen dan dukungan pemerintah berpengaruh terhadap kualitas hidup. Namun demikian dukungan pemerintah dan serikat pekerja tidak signifikan memoderasi pengaruh motivasi dan komitmen terhadap kualitas hidup.

Dalam model terpisah ditemukan bahwa komitmen berpengaruh signifikan terhadap kualitas hidup dan dimoderasi oleh dukungan pemerintah. Secara parsial dukungan serikat pekerja tidak memoderasi komitmen terhadap kualitas hidup, tetapi secara bersama-sama dukungan pemerintah dan dukungan organisasi signifikan memoderasi pengaruh komitmen terhadap kualitas hidup buruh perempuan di Jabodetabek. Dengan demikian peranan serikat pekerja dan Pemerintah menjadi penting dalam meningkatkan kualitas hidup buruh perempuan yang memiliki komitmen kontinuans yang tinggi. 


\section{Analisis Dukungan Organisasi ... (Sylvia D., Christine W., dan Benedicta E.)}

\section{Lampiran}

Tabel 1 : Conditional direct effect(s) of $\mathrm{X}$ on $\mathrm{Y}$ at values of the moderator(s)

\begin{tabular}{|c|c|c|c|c|c|c|c|}
\hline PDO & DSPI & Effect & $\mathrm{SE}$ & t & $\mathrm{p}$ & LLCI & ULCI \\
\hline 7,0000 & 4,0000 &, 1522 &, 1039 & 1,4659 &, 1453 &,- 0534 &, 3579 \\
\hline 7,0000 & 5,0000 &, 1456 &, 1011 & 1,4410 &, 1522 &,- 0545 &, 3457 \\
\hline 7,0000 & 8,0000 &, 1257 &, 1384 &, 9084 &, 3655 &,- 1483 &, 3998 \\
\hline 7,0000 & 10,0000 &, 1125 &, 1844 &, 6099 &, 5431 &,- 2527 &, 4776 \\
\hline 7,0000 & 10,0000 &, 1125 &, 1844 &, 6099 &, 5431 &,- 2527 &, 4776 \\
\hline 8,0000 & 4,0000 &, 1118 &, 1000 & 1,1180 & 2658 &,- 0862 &, 3099 \\
\hline 8,0000 & 5,0000 &, 1052 &, 0919 & 1,1451 &, 2544 &,- 0767 &, 2871 \\
\hline 8,0000 & 8,0000 &, 0853 &, 1200 &, 7106 &, 4787 &,- 1524 &, 3230 \\
\hline 8,0000 & 10,0000 &, 0720 &, 1652 &, 4362 &, 6635 &,- 2550 &, 3991 \\
\hline 8,0000 & 10,0000 & 0720 &, 1652 &, 4362 &, 6635 &,- 2550 &, 3991 \\
\hline 10,0000 & 4,0000 &, 0310 &, 1187 &, 2611 &, 7945 &,- 2040 &, 2659 \\
\hline 10,0000 & 5,0000 &, 0243 &, 1026 &, 2372 &, 8129 &,- 1789 & 2276 \\
\hline 10,0000 & 8,0000 &, 0045 &, 1028 &, 0434 &, 9655 &,- 1991 &, 2080 \\
\hline 10,0000 & 10,0000 &,- 0088 &, 1396 &,- 0631 &, 9498 &,- 2851 & 2675 \\
\hline 10,0000 & 10,0000 &,- 0088 &, 1396 &,- 0631 &, 9498 &,- 2851 &, 2675 \\
\hline 10,0000 & 4,0000 &, 0310 &, 1187 &, 2611 &, 7945 &,- 2040 &, 2659 \\
\hline 10,0000 & 5,0000 &, 0243 &, 1026 &, 2372 &, 8129 &,- 1789 &, 2276 \\
\hline 10,0000 & 8,0000 &, 0045 &, 1028 &, 0434 &, 9655 &,- 1991 &, 2080 \\
\hline 10,0000 & 10,0000 &,- 0088 &, 1396 &,- 0631 &, 9498 &,- 2851 &, 2675 \\
\hline 10,0000 & 10,0000 &,- 0088 &, 1396 &,- 0631 &, 9498 &,- 2851 &, 2675 \\
\hline 10,0000 & 4,0000 &, 0310 &, 1187 &, 2611 &, 7945 &,- 2040 &, 2659 \\
\hline 10,0000 & 5,0000 &, 0243 &, 1026 &, 2372 &, 8129 &,- 1789 &, 2276 \\
\hline 10,0000 & 8,0000 &, 0045 &, 1028 &, 0434 &, 9655 &,- 1991 &, 2080 \\
\hline 10,0000 & 10,0000 &,- 0088 &, 1396 &,- 0631 &, 9498 &,- 2851 &, 2675 \\
\hline 10,0000 & 10,0000 &,- 0088 &, 1396 &,- 0631 &, 9498 &,- 2851 &, 2675 \\
\hline
\end{tabular}

Sumber: Hasil Olahan untuk Penelitian 
Tabel 2: Conditional indirect effect(s) of X on $\mathrm{Y}$ at values of the moderator(s)

\begin{tabular}{|c|c|c|c|c|c|c|}
\hline \multicolumn{7}{|c|}{ Mediator } \\
\hline & PDO & DSPI & Effect & Boot $\mathrm{SE}$ & BootLLCI & BootULCI \\
\hline $\mathrm{CC}$ & 7,0000 & 4,0000 &, 0020 &, 0246 &,- 0416 &, 0560 \\
\hline $\mathrm{CC}$ & 7,0000 & 5,0000 &, 0031 &, 0347 &,- 0679 &, 0735 \\
\hline $\mathrm{CC}$ & 7,0000 & 8,0000 &, 0062 &, 0705 &,- 1470 &, 1460 \\
\hline $\mathrm{CC}$ & 7,0000 & 10,0000 &, 0083 &, 0954 &,- 2017 &, 1960 \\
\hline $\mathrm{CC}$ & 7,0000 & 10,0000 &, 0083 &, 0954 &,- 2017 &, 1960 \\
\hline $\mathrm{CC}$ & 8,0000 & 4,0000 &, 0014 &, 0193 &,- 0367 &, 0462 \\
\hline $\mathrm{CC}$ & 8,0000 & 5,0000 &, 0024 &, 0283 &,- 0561 &, 0614 \\
\hline $\mathrm{CC}$ & 8,0000 & 8,0000 &, 0055 &, 0636 &,- 1322 &, 1321 \\
\hline $\mathrm{CC}$ & 8,0000 & 10,0000 &, 0076 &, 0885 &,- 1829 &, 1881 \\
\hline $\mathrm{CC}$ & 8,0000 & 10,0000 &, 0076 &, 0885 &,- 1829 &, 1881 \\
\hline $\mathrm{CC}$ & 10,0000 & 4,0000 &, 0001 &, 0170 &,- 0316 &, 0358 \\
\hline $\mathrm{CC}$ & 10,0000 & 5,0000 &, 0012 &, 0193 &,- 0364 &, 0461 \\
\hline $\mathrm{CC}$ & 10,0000 & 8,0000 &, 0043 &, 0508 &,- 0957 &, 1115 \\
\hline $\mathrm{CC}$ & 10,0000 & 10,0000 &, 0064 &, 0754 &,- 1483 &, 1663 \\
\hline $\mathrm{CC}$ & 10,0000 & 10,0000 &, 0064 &, 0754 &,- 1483 &, 1663 \\
\hline $\mathrm{CC}$ & 10,0000 & 4,0000 &, 0001 &, 0170 &,- 0316 &, 0358 \\
\hline $\mathrm{CC}$ & 10,0000 & 5,0000 &, 0012 &, 0193 &,- 0364 &, 0461 \\
\hline $\mathrm{CC}$ & 10,0000 & 8,0000 &, 0043 &, 0508 &,- 0957 &, 1115 \\
\hline $\mathrm{CC}$ & 10,0000 & 10,0000 &, 0064 &, 0754 &,- 1483 &, 1663 \\
\hline $\mathrm{CC}$ & 10,0000 & 10,0000 &, 0064 &, 0754 &,- 1483 &, 1663 \\
\hline $\mathrm{CC}$ & 10,0000 & 4,0000 &, 0001 &, 0170 &,- 0316 &, 0358 \\
\hline $\mathrm{CC}$ & 10,0000 & 5,0000 &, 0012 &, 0193 &,- 0364 &, 0461 \\
\hline $\mathrm{CC}$ & 10,0000 & 8,0000 &, 0043 &, 0508 &,- 0957 &, 1115 \\
\hline $\mathrm{CC}$ & 10,0000 & 10,0000 &, 0064 &, 0754 &,- 1483 &, 1663 \\
\hline $\mathrm{CC}$ & 10,0000 & 10,0000 &, 0064 &, 0754 &,- 1483 &, 1663 \\
\hline
\end{tabular}

Sumber: Hasil Olahan untuk Penelitian 
Analisis Dukungan Organisasi ... (Sylvia D., Christine W., dan Benedicta E.)

Tabel 3:Conditional direct effect(s) of $\mathrm{X}$ on $\mathrm{Y}$ at values of the moderator(s)

\begin{tabular}{|rrrrrrrr|}
\hline DP & DSPI & Effect & SE & $t$ & $\mathrm{p}$ & LLCI & ULCI5 \\
5,0000 & 4,0000 &, 1108 &, 0940 & 1,1788 &, 2409 &,- 0754 &, 2971 \\
5,0000 & 5,0000 &, 1414 &, 0913 & 1,5496 &, 1239 &,- 0393 &, 3222 \\
5,0000 & 8,0000 &, 2332 &, 1472 & 1,5835 &, 1160 &,- 0585 &, 5248 \\
5,0000 & 10,0000 &, 2943 &, 2073 & 1,4195 &, 1584 &,- 1163 &, 7050 \\
5,0000 & 10,0000 &, 2943 &, 2073 & 1,4195 &, 1584 &,- 1163 &, 7050 \\
6,0000 & 4,0000 &, 0212 &, 0999 &, 2123 &, 8322 &,- 1767 &, 2191 \\
6,0000 & 5,0000 &, 0518 &, 0834 &, 6209 &, 5359 &,- 1134 &, 2170 \\
6,0000 & 8,0000 &, 1435 &, 1130 & 1,2703 &, 2065 &,- 0802 &, 3673 \\
6,0000 & 10,0000 &, 2047 &, 1704 & 1,2010 &, 2322 &,- 1328 &, 5422 \\
6,0000 & 10,0000 &, 2047 &, 1704 & 1,2010 &, 2322 &,- 1328 &, 5422 \\
8,0000 & 4,0000 &,- 1580 &, 1937 &,- 8156 &, 4164 &,- 5417 &, 2257 \\
8,0000 & 5,0000 &,- 1274 &, 1717 &,- 7422 &, 4594 &,- 4675 &, 2126 \\
8,0000 & 8,0000 &,- 0357 &, 1421 &,- 2512 &, 8021 &,- 3172 &, 2458 \\
8,0000 & 10,0000 &,, 0255 &, 1626 &,, 1566 &, 8758 &,- 2965 &, 3474 \\
8,0000 & 10,0000 &, 0255 &, 1626 &, 1566 &, 8758 &,- 2965 &, 3474 \\
9,0000 & 4,0000 &,- 2476 &, 2529 &,- 9793 &, 3294 &,- 7485 &, 2532 \\
9,0000 & 5,0000 &,- 2171 &, 2310 &,- 9396 &, 3494 &,- 6746 &, 2405 \\
9,0000 & 8,0000 &,- 1253 &, 1912 &,- 6555 &, 5134 &,- 5040 &, 2533 \\
9,0000 & 10,0000 &,- 0642 &, 1943 &,,- 3302 &, 7418 &,- 4490 &, 3206 \\
9,0000 & 10,0000 &,- 0642 &, 1943 &,- 3302 &, 7418 &,- 4490 &, 3206 \\
10,0000 & 4,0000 &,- 3373 &, 3143 & $-1,0731$ &, 2854 &,- 9597 &, 2852 \\
10,0000 & 5,0000 &,- 3067 &, 2927 & $-1,0477$ &, 2969 &,- 8864 &, 2730 \\
10,0000 & 8,0000 &,- 2149 &, 2476 &,- 8680 &, 3872 &,- 7054 &, 2755 \\
10,0000 & 10,0000 &,- 1538 &, 2398 &,- 6414 &, 5225 &,- 6286 &, 3211 \\
10,0000 & 10,0000 &,- 1538 &, 2398 &,- 6414 &, 5225 &,- 6286 &, 3211 \\
\hline
\end{tabular}

Sumber: Hasil Olahan untuk Penelitian

Tabel 4: Conditional indirect effect(s) of X on $\mathrm{Y}$ at values of the moderator(s)

\begin{tabular}{|c|c|c|c|c|c|c|}
\hline \multicolumn{7}{|c|}{ Mediator } \\
\hline & $\mathrm{DP}$ & DSPI & Effect & Boot SE & BootLLCI & BootULCI \\
\hline $\mathrm{CC}$ & 5,0000 & 4,0000 &, 1314 &, 0800 &,- 0163 &, 2994 \\
\hline $\mathrm{CC}$ & 5,0000 & 5,0000 &, 1583 &, 0829 &,- 0044 &, 3303 \\
\hline $\mathrm{CC}$ & 5,0000 & 8,0000 &, 2388 &, 1223 &,- 0100 &, 4887 \\
\hline $\mathrm{CC}$ & 5,0000 & 10,0000 &, 2924 &, 1609 &,- 0272 &, 6203 \\
\hline $\mathrm{CC}$ & 5,0000 & 10,0000 &, 2924 &, 1609 &,- 0272 &, 6203 \\
\hline $\mathrm{CC}$ & 6,0000 & 4,0000 &, 0363 &, 0700 &,- 0972 &, 1760 \\
\hline $\mathrm{CC}$ & 6,0000 & 5,0000 &, 0631 &, 0607 &,- 0463 &, 1904 \\
\hline $\mathrm{CC}$ & 6,0000 & 8,0000 &, 1436 &, 0820 &,- 0262 &, 3133 \\
\hline $\mathrm{CC}$ & 6,0000 & 10,0000 &, 1973 &, 1195 &,- 0486 &, 4415 \\
\hline $\mathrm{CC}$ & 6,0000 & 10,0000 &, 1973 &, 1195 &,- 0486 &, 4415 \\
\hline $\mathrm{CC}$ & 8,0000 & 4,0000 &,- 1541 &, 1230 &,- 4151 &, 0518 \\
\hline $\mathrm{CC}$ & 8,0000 & 5,0000 &,- 1272 &, 1027 &,- 3365 &, 0571 \\
\hline $\mathrm{CC}$ & 8,0000 & 8,0000 &,- 0467 &, 0591 &,- 1697 &, 0699 \\
\hline $\mathrm{CC}$ & 8,0000 & 10,0000 &, 0070 &, 0658 &,- 1410 &, 1272 \\
\hline $\mathrm{CC}$ & 8,0000 & 10,0000 &, 0070 &, 0658 &,- 1410 &, 1272 \\
\hline $\mathrm{CC}$ & 9,0000 & 4,0000 &,- 2492 &, 1639 &,- 5917 &, 0289 \\
\hline $\mathrm{CC}$ & 9,0000 & 5,0000 &,- 2224 &, 1436 &,- 5156 &, 0224 \\
\hline $\mathrm{CC}$ & 9,0000 & 8,0000 &,- 1419 &, 0922 &,- 3248 &, 0274 \\
\hline $\mathrm{CC}$ & 9,0000 & 10,0000 &,- 0882 &, 0773 &,- 2474 &, 0574 \\
\hline $\mathrm{CC}$ & 9,0000 & 10,0000 &,- 0882 &, 0773 &,- 2474 &, 0574 \\
\hline $\mathrm{CC}$ & 10,0000 & 4,0000 &,- 3444 &, 2074 &,- 7614 &, 0193 \\
\hline $\mathrm{CC}$ & 10,0000 & 5,0000 &,- 3176 &, 1873 &,- 6994 &, 0140 \\
\hline $\mathrm{CC}$ & 10,0000 & 8,0000 &,- 2370 &, 1339 &,- 5124 &, 0181 \\
\hline $\mathrm{CC}$ & 10,0000 & 10,0000 &,- 1834 &, 1097 &,- 4095 &, 0217 \\
\hline $\mathrm{CC}$ & 10,0000 & 10,0000 &,- 1834 &, 1097 &,- 4095 &, 0217 \\
\hline
\end{tabular}

Sumber: Hasil Olahan untuk Penelitian 


\section{DAFTAR PUSTAKA}

Allen, N. J., \& Meyer, J. P. (1990). The measurement and antecedents of affective, continuance, and normative commitment to the organization. Journal of Occupational Psychology, 63, 1-18.

Bano, Samina., Chaddha, Upasana., and Hussain, Sharnaz. 2015. Spiritual Intelligence, Quality of Life and Length of Service as Predictors of Organizational Commitment Among Power Sector Employees. Indian Journal of Positive Psychology 6 (1): 2631.

Bishop, J. W., \& Scott, D. K. (2000). An examination of organizational and team commitment in a self-directed team environment. Journal of Applied Psychology, $85,439-450$.

Bohlander, George W., and Snell, Scott A. 2013. Principles of Human Resource Management. 16ed. South-Western Cengage Learning.

Campbell, A., Converse, P. E. \& Rodgers, W. L. The Quality of American Life, Russell Sage Foundation, New York 1976.

Cheung, Chau-Kiu., and Leung, Kwok. 2010. Ways that Social Change Predict Personal Quality of Life. Social Indicators Research. Vol. 96, No. 3. Pp. 459-477.

Cohen-Charash, Y., \& Spector, P. E. (2001). The role of justice in organizations: A metaanalysis. Organizational Behavior and Human Decision Processes, 86, 278-321.

Eisenberger, R., Huntington, R., Hutchison, S., \& Sowa, D. (1986). Perceived organizational support. Journal of Applied Psychology,71, 500-507

Erben, Gul Selin., and Guneser, Ayse Begum. 2008. The Relationship Between Paternalistic Leadership and Organizational Commitment: Investigating The Role of Climat Regarding Ethics. Journal of Business Ethics, Vol. 82, No. 4, pp 955-968.

Hayes, A.F. (2013). Introduction To Mediation, Moderation, And Conditional Process Analysis A Regression - Based Approach (Series Editor's Notes by Little, D.T). The Guilford Press.

Inoguchi, Takashi., and Fujii, Seiji. 2009. The Quality of Life in Japan. Social Indicator Research. Vol, 92., No. 2., pp227-262.

Kongres Nasional Pembangunan Manusia dan Rapat Koordinasi Nasional Tim Koordinasi Penanggulangan Kemiskinan (TKPK) Tahun 2007. Seputar Indonesia: 17 Desember 2007.

Lazim, M. Abdullah \& Osman, M. Tap Abu. 2009. A New Malaysian Quality of Life Index Based on Fuzzy Sets and Hirarchical Needs, Social Indicators Research, Vol. 94. No.3. pp499-508.

Liden, R. C., Wayne, S., Kraimer, M. L., \& Sparrowe, R. T. (2003). The dual commitments of contingent workers: An examination of contingents' commitment to the agency and the organization. Journal of Organizational Behavior, 24, 609625 . 
Analisis Dukungan Organisasi ... (Sylvia D., Christine W., dan Benedicta E.)

Lim, Ghee Soon.,Mathis, Robert L., and Jackson, John H. 2010. Human Resource Management: An Asia Edition. Cengage Learning.

Meyer, J. P., \& Allen, N. J. (1997). Commitment in the workplace: Theory, research, and application. Thousand Oaks: Sage.

Milkovich, George., Newman, Jerry., and Gerhart, Barry. 2014. Compensation. 11ed. McGraw-Hill International Edition.

Moon, M. Jae. 2000 Organizational Commitment Revisited in New Public Management: Motivation, Organizational Culture, Sector, and Managerial Level. Public Performance \& Management Review, Vol. 24, No. 2. pp. 177-194

Pencavel, John. 2009, How Successful Have Trade Unions Been? A Utility-Based Indicator of Union Well-Being, Industrial and Labor Relations Review, Vol.62, No.2 pp.147156

Purba, Sylvia D., 2014.Effect of Work-Life Balance and Antecedent Variable on Intention to Stay (A Study of Female Employees in High Performing Banks in Jakarta, International Journal of Management and Information Technology, Vol.8 No.3. 2014

Rini, Koordinator Hubungan Internasional Aksi Perempuan Indonesia (API) Kartini http://www.berdikarionline.com/opini/20150501/potret-buram-buruh-perempuanindonesia-di-bawah-neoliberalisme.html

Skevington, S.M., Lotfy M., O’Connel K.A., (2004). The World Helath Organization's WHOQOL-BREF. Quality of Life Assessment: Psychometric Properties and Results of the International Field Trial A Report from the WHOQOL Group, Quality uf Life Research. 13: 299-310.

Sharma, Madan Pal. 1997. Organisational Commitment and Its Determinants. Indian Journal of Industrial Relations, Vol. 33, No. 2, pp193-210.

Taing, Meng U., Granger, Benjamin P., Groff, Kyle W., Jackson, Erin M,m and Johnson, Russel E. (2011). The Multidimensional Nature of Continuance Commitment: Commitment Owing to Economic Exchanges Versus Lack of Employment Alternatives. Journal of Business and Psychology, Vol. 26, No. 3, pp. 269-284.

Undang-Undang 13/2003 tentang Ketenagakerjaan

Undang-Undang 21/2000 tentang Serikat Pekerja/Serikat Buruh

Undang-Undang no. 2/2004 tentang Penyelesaian Perselisihan Hubungan Industrial

Warren, Tracey., Fox, Elizabeth., \& Pascall, Gillian. (2009). Innovative social policies: Implications for work-life balance among low waged women in England. Gender, Work and Organization.Vol.16. No.1.

Widiyanto, Strategi Peningkatan Kualitas Hidup Manusia di Indonesia Artikel Gagasan. Anggota Peer Group Pusat Penelitian Kependudukan (PPK) LPPM UNS Solo diunduh si.uns.sc.id. 1 Oktober 2015. 
Journal of Management Vol.13, No.1, January 2016: 41-87 and Business Review

Wittmer D. (1991). Serving the people or serving for pay: Reward preferences among government, hybrid sector, and business managers. Public Productivity \& Management Review, 1 4, 369-383.

Zeytinoglu, I. U., M. Denton, S. Davies, A. Baumann, J. Blythe, and L. Boos. 2007. Associations between work intensification, stress, and job satisfaction, the case of nurses in Ontario. Relations Industrielles 62 (2):201. 